\title{
SPENT NUCLEAR FUEL REMOVAL PROGRAM AT THE WEST VALLEY DEMONSTRATION PROJECT
}

Topical Report

By

B. J. Connors

M. P. Golden

P. J. Valenti

J. J. Winkel

March 1987

Work Performed Under Contract No. AC07-81NE44139

West Valley Nuclear Services Co., Inc.

West Valley, New York 


\section{DISCLAIMER}

This report was prepared as an account of work sponsored by an agency of the United States Government. Neither the United States Government nor any agency Thereof, nor any of their employees, makes any warranty, express or implied, or assumes any legal liability or responsibility for the accuracy, completeness, or usefulness of any information, apparatus, product, or process disclosed, or represents that its use would not infringe privately owned rights. Reference herein to any specific commercial product, process, or service by trade name, trademark, manufacturer, or otherwise does not necessarily constitute or imply its endorsement, recommendation, or favoring by the United States Government or any agency thereof. The views and opinions of authors expressed herein do not necessarily state or reflect those of the United States Government or any agency thereof. 


\section{DISCLAIMER}

Portions of this document may be illegible in electronic image products. Images are produced from the best available original document. 


\section{DISCLAIMER}

This report was prepared as an account of work sponsored by an agency of the United States Government. Neither the United States Government nor any agency thereof, nor any of their employees, makes any warranty, express or implied, or assumes any legal liability or responsibility for the accuracy, completeness, or usefulness of any information, apparatus, product, or process disclosed, or represents that its use would not infringe privately owned rights. Reference herein to any specific commercial product, process, or service by trade name, trademark, manufacturer, or otherwise does not necessarily constitute or imply its endorsement, recommendation, or favoring by the United States Government or any agency thereof. The views and opinions of authors expressed herein do not necessarily state or reflect those of the United States Government or any agency thereof.

This report has been reproduced directly from the best available copy.

Available from the National Technical Information Service, U. S. Department of Commerce, Springfield, Virginia 22161.

\section{Price: Printed Copy A06}

Microfiche A01

Codes are used for pricing all publications. The code is determined by the number of pages in the publication. Information pertaining to the pricing codes can be found in the current issues of the following publications, which are generally available in most libraries: Energy Research Abstracts (ERA); Government Reports Announcements and Index (GRA and 1); Scientific and Technical Abstract Reports (STAR); and publication NTIS-PR-360 available from NTIS at the above address. 
DOE/NE/44139-37

(DE88002634)

Distribution Category UC-70

\title{
SPENT NUCLEAR FUEL REMOVAL PROGRAM \\ AT THE \\ WEST VALLEY DEMONSTRATION PROJECT
}

\author{
By \\ Bernard J. Connors \\ Martin P. Golden \\ Paul J. Valenti \\ Jeffrey $J$. Winkel
}

Work Performed Under Contract No. DE-ACO7-81NE 44139

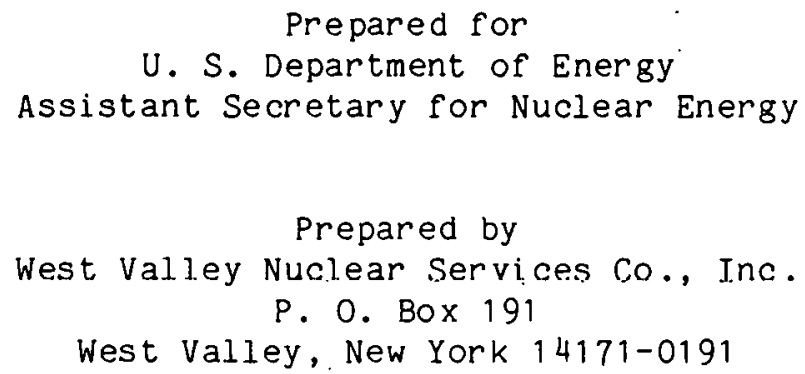


THIS PAGE

\section{WAS INTENTIONALLY LEFT BLANK}


SPENT NUCLEAR FUEL REMOVAL PROGRAM

AT THE

WEST VALLEY DEMONSTRATION PROJECT

\section{TABLE OF CONTENTS}

Page

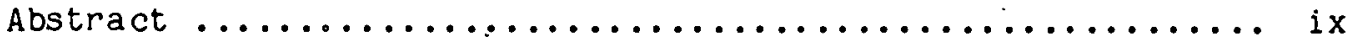

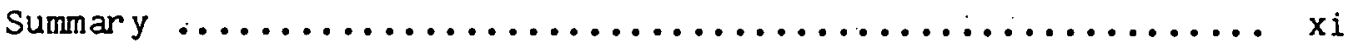

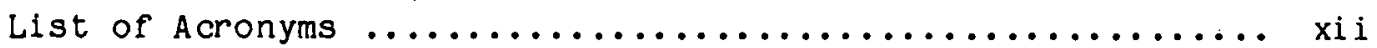

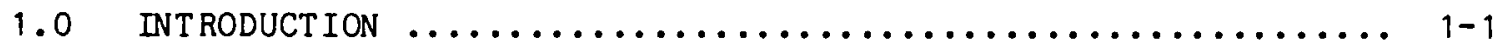

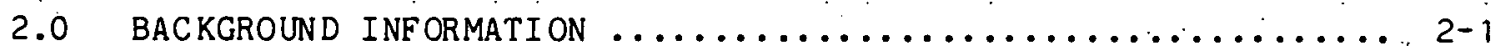

2. 1 Nuclear Fuel Services, Inc. ................ $2-1$

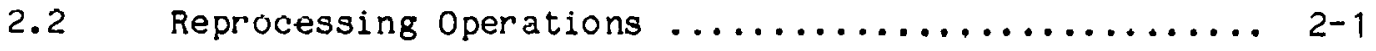

2.3 Fuel Receiving and storage Pool at west valley ..... 2-2

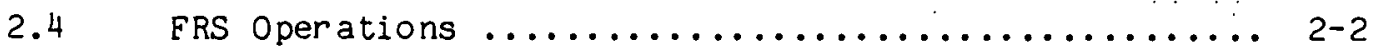

2.5 Storage of SNF Assemblies $\ldots \ldots \ldots \ldots \ldots \ldots \ldots \ldots \ldots . \ldots \ldots$

2.6 New York State and Legal Actions ............. 2-3

2.6 .1 Scenario .............................. $2-3$

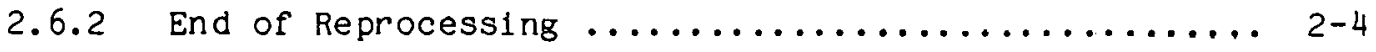

2.6.3 West Valley Demonstration Project (WVDP) ......... 2-4

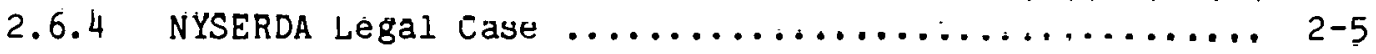

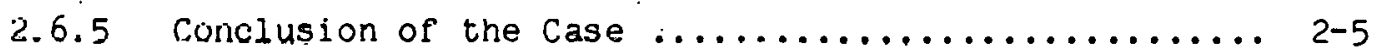

2.6.6 Authority to Ship SNF Assemblies ............. 2-6

2.6.7 Contractor and Shipping Agent ............... 2-6

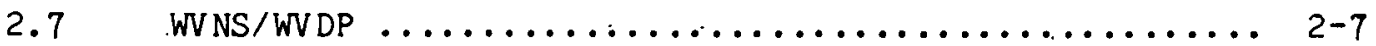

2.8 Removal of Spent Nuclear Fuel Assemblies ......... 2-7

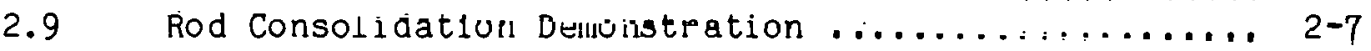


TABLE OF CONTENTS -(conti nued)

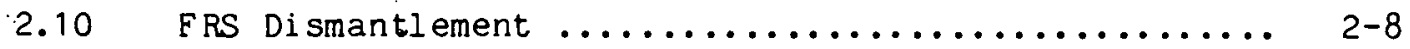

2. 11 Future Volume Reduction in FRS ............... 2-8

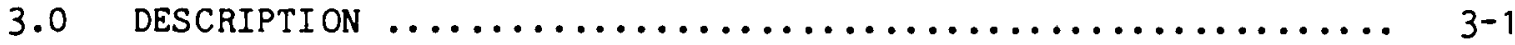

3.1 WVDP Site and Plant. ....................

3.2 Fuel Receiving and Storage Facility (FRS) $\ldots \ldots \ldots \ldots$ 3-1

3.2.1 Cask Unloading Pool ..................... 3-.

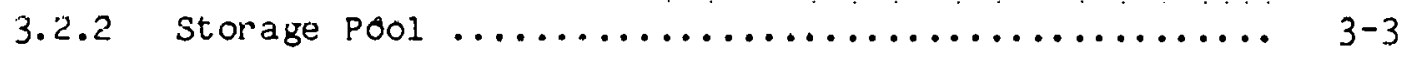

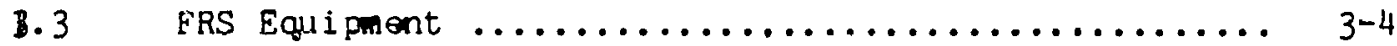

3.3.1 $90.7 \mathrm{Mg}$ (100-Ton) Cask Crane ............... 3-4

3.3.2. Cask Lifting Yoke ...................... 3-6

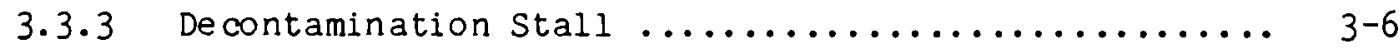

3.3.3. 1 Cask Washdown system .................... 3-6

3.3.3.2 Decontamigation Stal. I Ventilation System $\ldots . . . \ldots . .3-7$

3.3.4 Clearwell Bucket and Lifting Yoke ............. 3-7

3.3 .5 Cask Lid Spider ........................ 3-9

3.3 .6 Fuel Grapples $\ldots \ldots \ldots \ldots \ldots \ldots \ldots \ldots \ldots \ldots \ldots \ldots . \ldots \ldots$

3.3 .7 CUP Servlue Briage .......................... 3-9

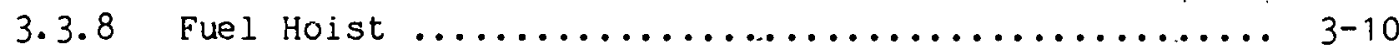

3.3.9 Canister Lift Rack ....................... 3-10

3.3.10 Fuel Storage Pool Bridge ................... 3-11

3.3.11 Canister $6 r$ ane .......................... 3-11

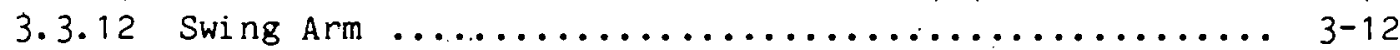

3.4 FRS Pool water Treatment System $\ldots \ldots \ldots \ldots \ldots \ldots \ldots . \ldots \ldots \ldots$

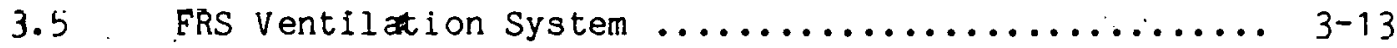

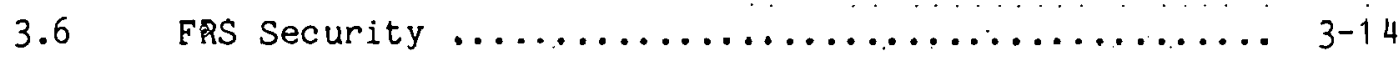

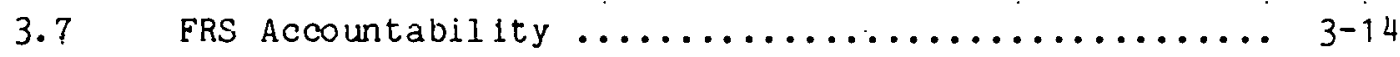

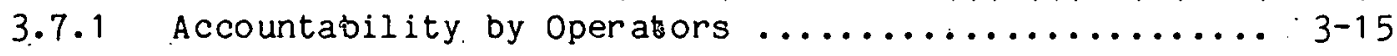

3.7.2. Accountability by the Accountability Representative - 3-16

4.0 CASK HANDLING AND UNLOADING PROCEDURES $\ldots \ldots \ldots \ldots \ldots \ldots \ldots \ldots$. $4-1$

4.1 Receiving and Preparation for Unloading .......... 4-i 
TABLE OF CONTENTS (continued)

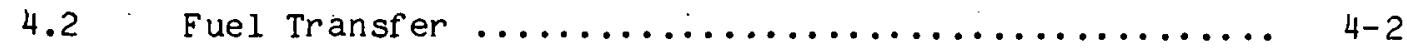

4.3 Removal from CUP and Preparation for Return Shipment 4-2

4.4 Summary of Fuel Received ................. 4-3

4.5 Operating $T$ ime and Exposure $\ldots \ldots \ldots \ldots \ldots \ldots \ldots \ldots . \ldots \ldots$ 4-3

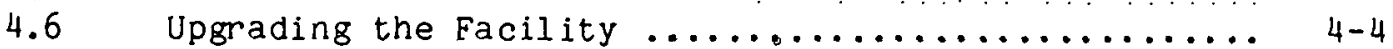

5.0 SPENT NUCLEAR FUEL (SNF) INVENT ORY IN FRS $\ldots \ldots \ldots \ldots \ldots \ldots \ldots . . \ldots$

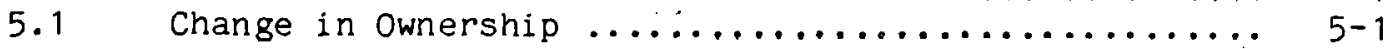

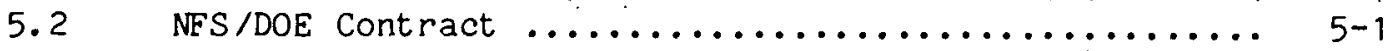

5.3 Description of SNF Assemblies in FRS .......... $5-1$

5.4 Condition of SNF Assemblies ................. 5-2

6.0 SNF SHIPPING CAMPAIGNS FROM WEST VALLEY $\ldots \ldots \ldots \ldots \ldots \ldots \ldots .6 .1$

6.1 Point Beach Shipping Campaign ................ 6-1

6.2 Dresden Shipping Campaign $\ldots \ldots \ldots \ldots \ldots \ldots \ldots \ldots \ldots . \ldots \ldots$ 6-1

6.3 Oyster Creek Shipping Campaign $\ldots \ldots \ldots \ldots \ldots \ldots \ldots \ldots$ 6-3

6.4 Ginna Shipping Campaign ................... $6-5$

$6.5 \quad$ INEL Shipping Campaigns $\ldots \ldots \ldots \ldots \ldots \ldots \ldots \ldots \ldots . \ldots \ldots 6 . \ldots \ldots$

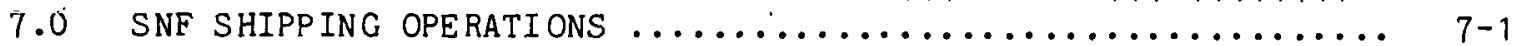

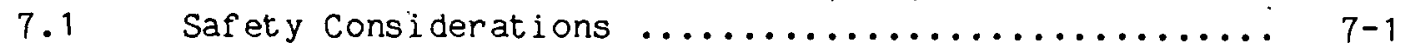

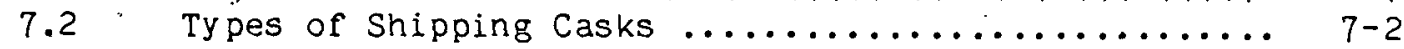

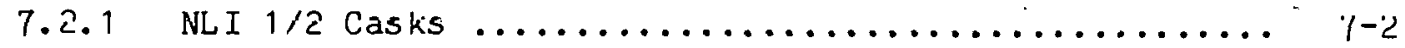

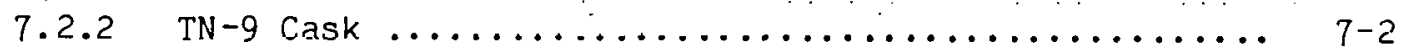

7.2.3 $90.7 \mathrm{Mg}(100-\mathrm{Ton})$ Dual Storage Cask ........... 7-3

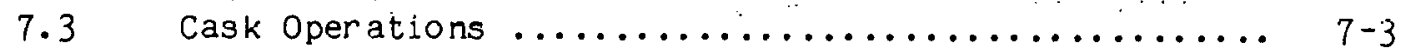

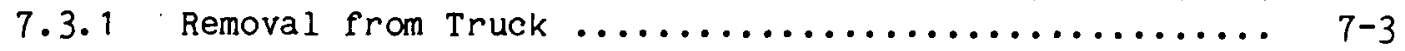

7.3.2 Prepping the Empty Cask .................. $7-3$

7.3.3 Clearwell Bucket and Vinyl Cover ................. $7=4$

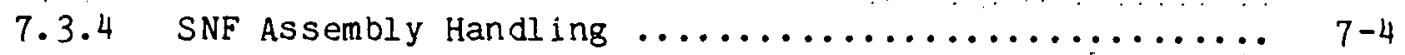

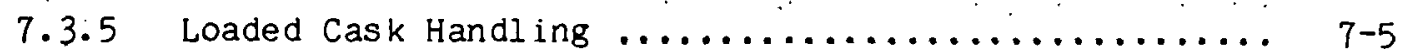

7.3.6 Placing the Cask on the Truck ................. $7-6$

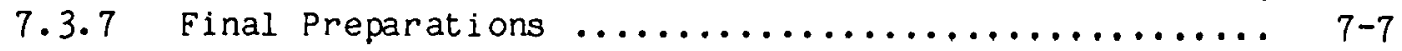


TABLE OF CONTENTS (continued)

7.3.8 Operations for the Other Casks $\ldots \ldots \ldots \ldots \ldots \ldots \ldots \ldots$ 7-8

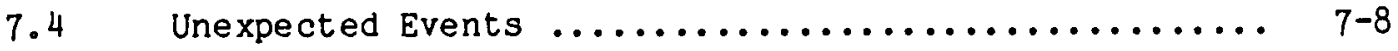

7.4.1 The Red oxide Problem .................... 7-9

7.4.2 Bowed and Twisted SNF Assemblies ............. 7-9

7.4.3 Damaged Fuel Rods ........................ 7-9

7.4 .4 Distorted Grids ........................ 7-10

7.4.5 Regulatory Problems ..................... 7-10

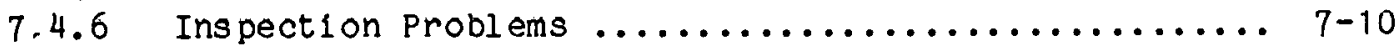

7.5 Fuel Rod Consolidation Program ................ 7-11

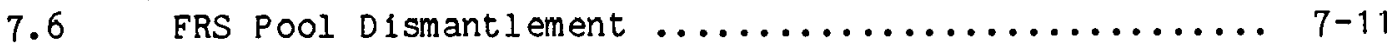

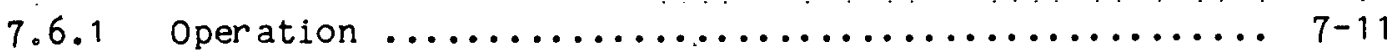

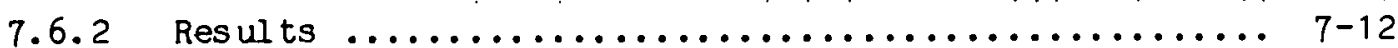

8.0 PUBLIC ISSUES AND RESPONSES $\ldots \ldots \ldots \ldots \ldots \ldots \ldots \ldots \ldots \ldots \ldots \ldots \ldots \ldots$

8.1 General Public ......................... 8-1

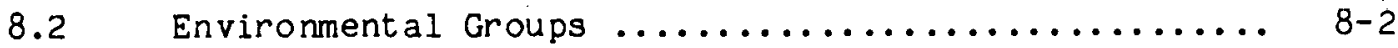

8.3 Public officials ...................... 8-2

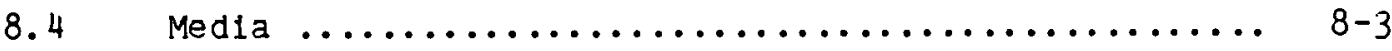

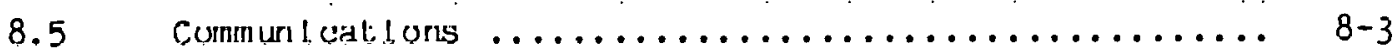

9.0 SCHEDULE, $\cos \mathrm{T}$, EXPOSURE AND WASTE DATA $\ldots \ldots \ldots \ldots \ldots \ldots \ldots . .$.

9.1 Planning and Preparation for Shipout Campaigns ..... 9-1

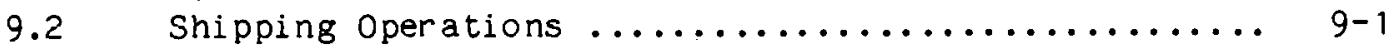

9.3 Fuel Rod Consolidation .................... 9-2

9.4 FRS Pool Dismantlement ................... 9-?

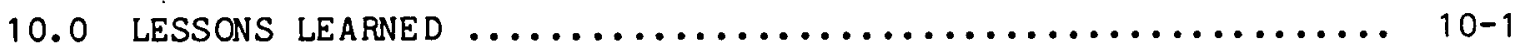

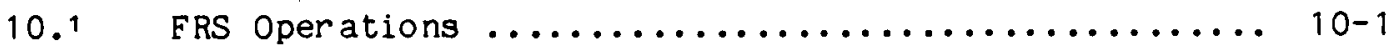

10.2 Preparation for SNF Removal Campaigns ........... 10-1

10.3 Shipping Operations .................... 10-1

10.4 Fuel Rod Consolidation .................... 10-2

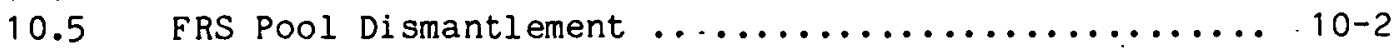

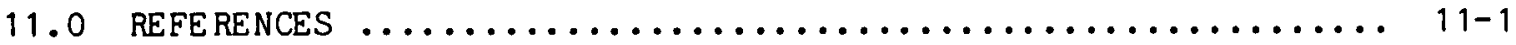




\section{FIGURES}

Number

Page

1. Plant-Identifying Fuel Receiving and Storage Facility Location .................................. 3-18

2. West Valley Fuel Receiving and Storage, Plan ........... 3-19

3. West Valley Fuel Receiving and Storage, Elevation ......... 3-20

4. Storage Racks with Canisters ........................ 3-21

5. Cask Unloading Crane and CUP ......................... 3-22

6. Fuel Storage Pool Bridge ......................... 3-...

7. Truck and Rail Casks ........................... $4-6$

8. Removing Cask from Trailer ......................... 4-.

9. Installing Cask in Decontamination stall ..............

10. Lowering Cask in Clearwell Bucket .................... 4-.

11. Storage Pool with Loaded Canisters .................... 4-10

12. Fuel Storage Positions, $12 / 31 / 80 \ldots \ldots \ldots \ldots \ldots \ldots \ldots \ldots \ldots$

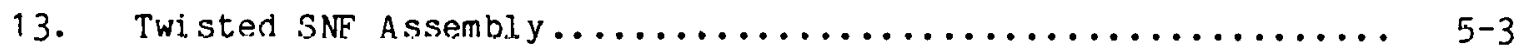

14. NLI Cask Being Lifted and Ready for Transport........... $7-14$

15. TN-9 Cask in the FRS Decon Stall and as Rigged

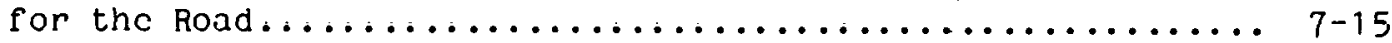

16. TN-9 Cask Belng Withdrawn From the Pool ............... 
\begin{tabular}{ll} 
Number & Page \\
\hline
\end{tabular}

1. Spent Nuclear Fuel in FRS ...........................4 $4-5$

2. West Valley Spent Fuel shipments .....................6-7

3. West Valley to Dresden Shipping Campaign...............6-8

4. West Valley to Point Beach Shipping Campaign ..............6-9

5. West Valley to Ginna Shipping Campaign................ 6-10

6. West Valiey to oyster Creek Shipping Campaign ............6-11

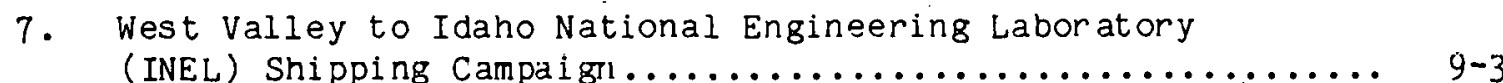

8. Manpower Involved in Shipping one Cask.................. 9-4

9. SNE Removal Program Data Summary..................... 


\title{
SPENT NUCLEAR FUEL REMOVAL PROGRAM \\ AT THE \\ MEST VALLEY DEMONSTRATION PROJECT
}

\author{
Bernard J. Connors \\ Martin P. Golden \\ Paul J. Valenti \\ Jeffrey J. Winkel
}

\begin{abstract}
The world's first. commercial nuclear fuel reprocessing plant at west valley, New York, was in the process of tripling its capacity when, due to economic considerations of new regulatory requirements, plant operations were suspended. However, the plant did continue the storage of spent nuclear fuel assemblies for utility customers. Thereafter the plant ownership reverted to the New York State Energy Research and Development Authority. Subsequently, with the Congressional enactment of the West Valley Demonstration Project Act (WVDPA), the U.S. Department of Energy assumed operational control of the plant in February 1982. At that time there were 750 spent nuclear fuel (SNE) assemblies stored underwater in the plant's Fuel Receiving and Storage (FRS) pool.
\end{abstract}

In order to meet the WVDPA objectives, which included decontamination and decommissioning areas of the plant, and utilizing as much of the existing plant as practical, this FRS pool would be required for size reduction operations. This required the removal of the 750 spent nuclear fuel assemblies and returning them to their owners.

The spent nuclear fuel removal programs at the West Valley Demonstration Project have resulted in the safe removal by truck transportation of 625 of lhese SNF dssemblies to their utility owners. The remaining 125, which are under DOE control, are scheduled to be shipped to a government site in Idaho. 
In addition to this removal program, a spent fuel rod consolidation demonstration has been completed, and"the storage canisters and their racks are being removed from the FRS pool to make way for installation of the size reduction equipment. 


\section{SUMMA RY}

The spent nuclear fuel removal program at the West Valley Demonstration Project (WVD) consisted of removing the spent nuclear fuel (SNF) assemblies from the storage pool in the plant, loading them in shielded casks, and preparing the casks for transportation. The utility and government owners of the fuel assemblies were responsible for providing the transportation.

So far, four fuel removal campaigns have been completed with the return of 625 spent nuclear fuel assemblies to their four utility owners. A fifth campaign, which is not yet completed, will transfer the remaining 125 fuel assemblies to a government site in Idaho.

In addition to this removal program, a spent fuel rod consolidation demonstration has been completed, and the storage canisters and their racks are being removed from the fuel receiving and storage pool to make way for installation of the size reduction equipment.

The four conpleted campaigns, which took place from October 1983 to May 1986, and including the rod consolidation demonstration and removal of the storage canisters, resulted in the expenditure of $\$ 3911 \mathrm{~K}$. The radiological exposure during these sampaigns was 42.1 Man Rem. The low level waste generated was 320.2 cubic metres, including 254.7 cubic metres from storage canister removal.

A brief history of the West Valley reprocessing plant and the events leading to the storage and ownership of the spent nuclear $f$ uel assemblies and their subsequent removal from west valley are also recorded in this report as background information. 


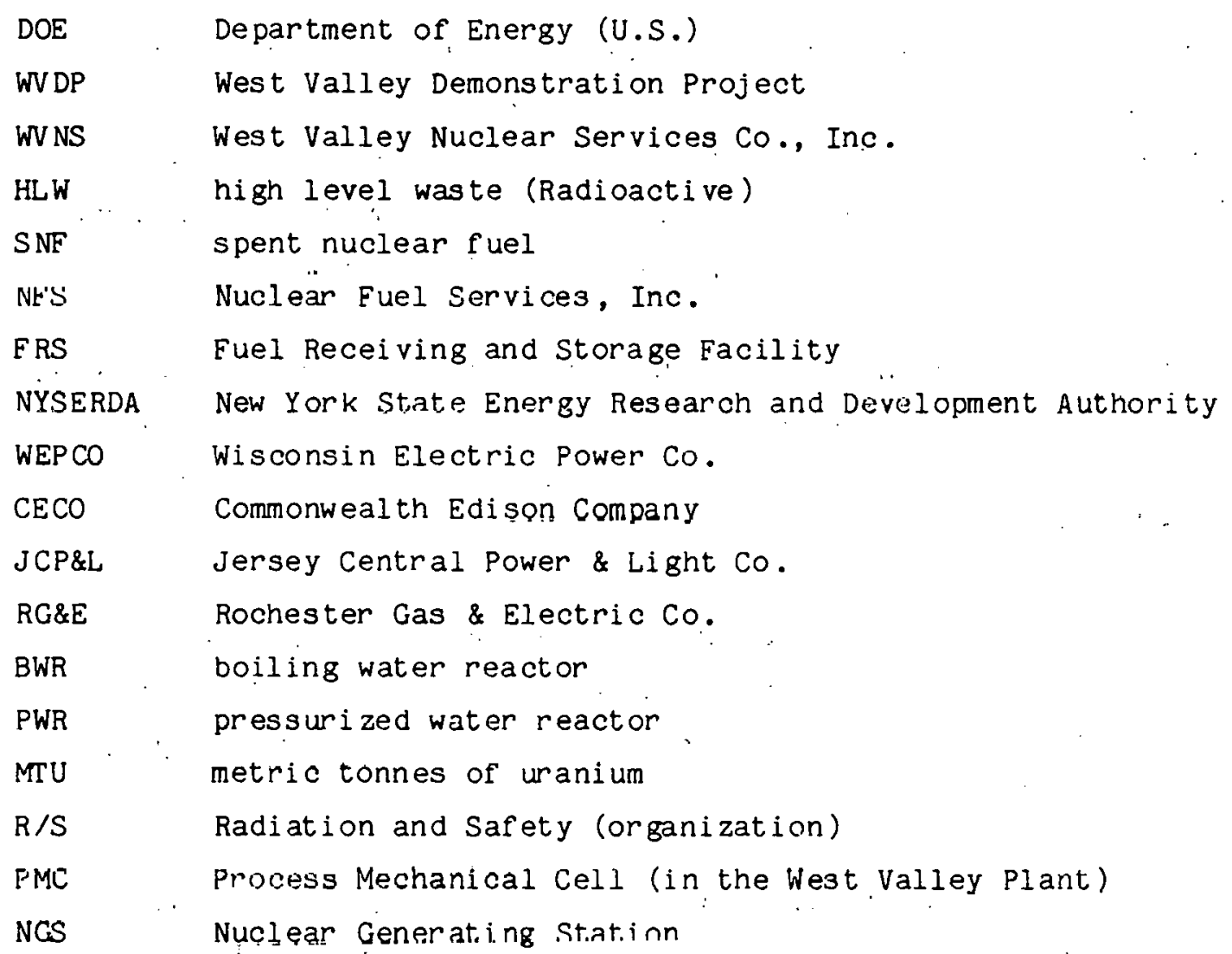




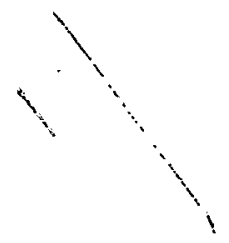

\subsection{INTRODUCTION}

The U. S. Department of Energy (DOE) has been directed by an act of Congress (The West Valley Demonstration Project Act of 1980, Public Law 96-368) to carry out the West Valley Demonstration Project (WVDP) at West Valley, New York. West Valley is the site of the world's first commercial nuclear fuel reprocessing plant. As a result of plant operations from 1966 to $1972,2,120 \mathrm{~m}^{3}$ (560,000 gallon) of 1iquid high level waste (HLW) were generated and are presently stored in underground tanks. The primary objective of the WVDP is the solidification of this liquid HLW in a glass form. West Valley Nuclear Services Company, Inc. (WVNS), a subsidiary of the Westinghouse Electric Corporation, was selected by the DOE to be the prime contractor for the project.

The WVDP policy is to utilize existing plant facilities to the maximum practical extent for installation of the high level radioactive waste (HLW) solidification process and its support systems. This has required extensive decontamination and dismantlement of existing plant vessels and equipment.

To effectively and economically dispose of these contaminated vessels and equipment, underwater cutting and decontamination operations will be required for volume and size reduction. The water provides the required radiation shielding while permitting good visual observation and handling of the operations.

The Fuel Receiving and Storage (FRS) facility at the WVDP reprocessing plant includes a large storage pool which is ideal for these operations. Before it can be used, however, the majority of the spent nuclear fuel (SNF) assemblies in storage must be removed. This report describes removal of the SNF assemblies from the pool and their shipment to their utilit.y or government owners. 


\subsection{BACKGROUND INFORMATION}

2.1 Nuclear Fuel Services Inc.

The West Valley facility, which was built and operated by Nuclear Fuel Services Inc., (NFS), handled and processed fuels from nine different reactors during 28 campaigns over the six-year period from 1966-1972. The experience gained in shipping, handling and storing these first-generation SNF assemblies resulted in considerable modifications and changes to the equipment, systems, procedures and concepts. These changes were made during and after the plant shutdown and cleanup in 1972.

The NFS Reprocessing Plant at West Valley was not only the world's first commercial nuclear fuel reprocessing plant, but it was also the first and America's only operating multi-purpose reprocessing plant. It was designed to handle and reprocess a variety of SNF assemblies from the beginning of the commercial nuclear power industry, including low and high enriched uranium, breeder, and thorium nuclear fuels.

These fuels of all descriptions--metals, oxides and mixtures--were shipped by both rail and truck, but the initial cmphaeis wae on rail shipments because of the shielding, bulk, and the effective payload.

\subsection{Reprocessing Operations}

Since high level radioactive waste. (HLW) is defined as the highly radioactive waste material that results from the reprocessing of spent nuclear fuel (per DOE Order ID 5820.2, Item $6 \mathrm{~m}$ ), all of the commercially produced $\mathrm{HLW}$ in the U. S. is and has been stored in the underground tank designated $8 \mathrm{D}-2$ at the west valley site. 
From 1966 until fuel reprocessing was halted in 1972, approximately. 2,000 SNF assemblies in 341 separate rail and truck shipments were received at west Valley. Those shipments for reprocessing operations represent some 941,440 cask kilometers $(585,000$ cask miles) of fuel shipping and cask handling experience.

\subsection{Fuel Receiving and Storage Pool at West Valley}

In November 197.2, after the NFS scheduled shutdown of operations for modifications and expansion, the fuel receiving and storage (FRS) pool was emptied, decontaminated to $50-500 \mathrm{dpm}$ alpha/100 $\mathrm{cm}^{2}$ and/or $500-50,000 \mathrm{dpm}$ beta/100 $\mathrm{cm}^{2}$ surface contamination levels, inspected and repaired. A $1829 \mathrm{~mm}(6 \mathrm{ft})$ to $2438 \mathrm{~mm}(8 \mathrm{ft}$ ) bulge in the lower sections of the stainless steel liner in the southwest corner of the pool's cask handling area was repaired at that time.

\subsection{FRS Operations}

From February 1973 to December 1975, 756 SNF assemblies containing $16 b$ tonnes of uranium spent fuel were shipped to west valley for storage. During 1978, six PWR type SNF assemblies belonging to Wisconsin Electric Power. Co. were removed from the FRS storage pool and shipped to Battelle Pacific Northwest Laboratories:, thus reducing the fuel storage inventory to its pre-removal program level of 163 metric tonnes. There have been 415 individual cask receipt3, 405 by truck and 10 by rail, representing approximately 280,000 total cask kilometers $(174,000$ cask miles) of fuel shipping experience. Not covering the return shipments, the combined 17 years of receiving and storage experience represents 756 cask receipts with over $2,756 \mathrm{SNF}$ assemblies and a total of approximately $1,175,000$ cask kilometers $(730,000$ cask miles). 


\subsection{Storage of SNF Assemblies}

SNF assemblies of 165 metric tonnes of uranium (MTU) from both boiling water reactor (BWR) and pressurized water reactors (PWR) type nuclear power reactors were being stored at west Valley in a critically safe array under $3353 \mathrm{~mm}$ ( $11 \mathrm{feet}$ ) of water. An additional 85 MTU of licensed storage capacity was still available in the fuel st.nrage nonl. Ry equipping the storage pool with a borated aluminum crating arrangement, a fairly common practice, done at many reactor plants, the storage pool capacity could have been expanded to hold up to $1,500 \mathrm{MTU}$.

During the FRS pool operations since 1972, there has been no measurable leakage of pool water or radionuclides to the environment through breach of the liner or wall integrity, nor have there been any incidents of overexposure to personnel. There have been relatively few non-routine events that required special handling, and there have been no detrimental effects on the SNF assemblies due to the WVDP fuel handling operations.

\subsection{New York State and Legal Actions}

\subsubsection{Scenario}

In the early 1960s, New York State entered into a contractual agreement with Nuclear Fuel Services, Inc. (NFS) to build and operate a commercial spent fuel reprocessing facility at a site approximately $48 \mathrm{~km}$ ( $30 \mathrm{miles}$ ) south of Buffalo, New York. One of the provisions of the contract was that New York State would assume ownership of the facility, now known as the Western New York Nuclear Service Center, if for any reason NFS did not renew its contract upon expiration in 1980, In the late 19603 and early 1970s, NFS set about 
entering into contractual agreements with various.nuclear utilities to supply reprocessing services for SNF assemblies generated by these utilities. Implicit in those agreements $\therefore$ were the transport of SNF assemblies to the West Valley facility, and the subsequent storage there until reprocessing services pursuant to contractual negotiations were completed.

\subsubsection{End of Reprocessing}

In September 1976, however, NFS withdrew from the reprocessing business, leaving 756 nuclear fuel assemblies (163 MTU) stored in the West Valley FRS stonrage nnnl. Now York State Energy Research and Development Authority (NYSERDA) subsequently assumed ownership of the West Valley facility when NFS failed to renew its contract in 1980.

\subsubsection{West Vallcy Dcmonotration Frojeet (WVDP)}

In 1980, Congrese onactcd P:L: 96-368, the West valley

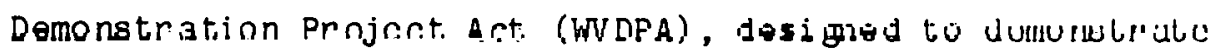
solutions for nuclear waste disposal. The Department of Energy (DOE) was given the authority and responsibility for implementing the WVDPA and, in connection with this assignment, assumed operational control of the west valley facility in 1982. NYSERDA remained the owner. The WVDP is intended to develop and demonstrate solidification techniques that can be used to prepare HLW for disposal. 


\subsubsection{NYSERDA Legal Case}

In 1981, NYSERDA advised the owners of the SNF assemblies stored at the west Valley facility that continued storage of utility-owned SNE assemblies by NFS was improper due to termination of the lease to NFS in December 1980. The owners of the SNF assemblies were:

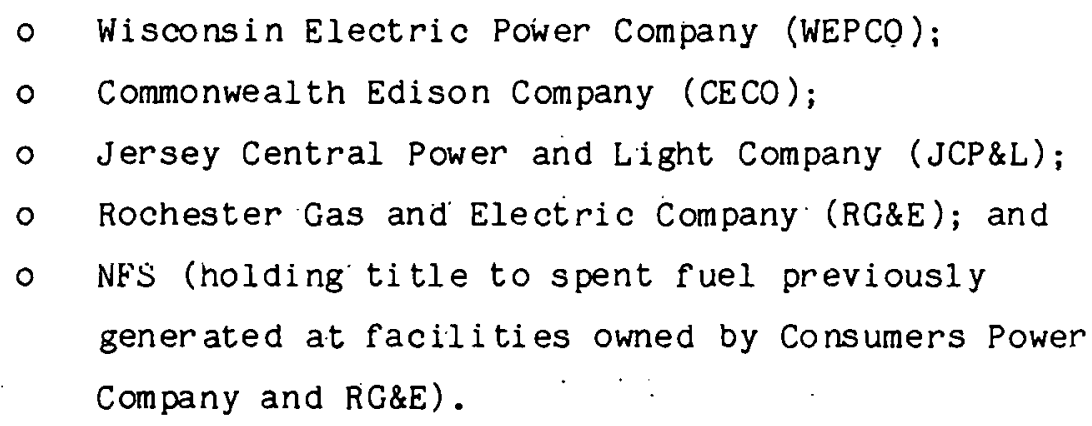

Due to a dispute between NYSERDA and certain owners of the SNF assemblies stored at West Valley, NYSERDA initiated legal action in the U.S. District Court of New York in May 1982 against NFS, WEPCO, CECO, JCP\&L and others, alleging that their right to store SNE assemblies at the West Valley facility had expired coincident with expiration of the NFS lease. In the legal action, NYSERDA cited to the court that implementation of the WVDPA cannot be completed while utility and NES owned $S N F$ assemblies remain in the west Valley FRS storage pool, and that failure to remove the fuel commencing in the fall of 1983 would entail serious consequences to the national interest in solving nuclear waste problems (U.S. Court of Appeals, 1985).

\subsubsection{Conclusion of the Case}

After extensive document discovery, depositions, hearings, and rulings in April, Junc, and september 1903, a filld District Court Order was issued in October 1983, directing 
all owners of SNF assemblies stored at West Valley to remove them or face trespassing charges and other penalties (U.S. District Court, 1983). RG\&E was not a litigant in the NYSERDA versus NFS et al., court action, having negotiated an out-of-court agreement with NYSERDA for removal of its SNE assemblies. NFS subsequently gave title-to its SNF assemblies stored at West Valley to DOE, setting the stage for the planned DOE-managed West Valley to Idaho National Engineering Laboratory (INEL) shipping campaign.

\subsubsection{Authority to Ship SNF Assemblies}

During tho NYSERDA oaeo litigation, 3 number of developments occurred that shaped the final scenario for the start of SNF assemblies shipping campaigns from the West valley facility to the respective storage sites designated by owners of the SNF assemblies. One such development was a Sierra Club inquiry (August 1983) concerning the authority of WEPCO, CECO, JCP\&L, and RG\&E to ship SNF assemblies from west Valley without amendment of their general license issued by the NRC. This issue was solved by issuance of an administrative law decision by the NRC, which allowed the utilities under court order to ship SNE assemblies from West Valley without a license amendment and to delegate their quality assurance functions under $10 \mathrm{CFR}$ Part 71 to a contract.or.

\subsubsection{Contractor. and Shipping Agent}

In essence, DOE, who had assumed overall control of the West Valley facility pursuant to the DOE,NYOERDA Agreement, became this contractor, and in conjunction with its contractor, WVNS also became the on-site loading agent for the four utilities with SNE assemblies at West Valley. The DOE certified to the utilities that the packages were properly loaded for shipment in accordance with their approved procedures. The utilities, through their on-site representatives, acted as the shipping agents. 


\subsection{WVNS/WVDP}

WVNS has been contracted by DOE to conduct a HLW demonstration project, which is the WVDP. Approximately $2,120 \mathrm{~m}^{3}(560,000$ gallons) of liquid HLW, stored underground in steel tanks, will be solidified into a glass form. Certain existing facilities within the plant have been identified for use in support of the solidification program. These facilities, which for the most part are shielded cells, have been and are being decontaminated and dismantled.

The FRS facility has been identified for use in support of the HLW solidification program. It is to be emptied of SNF assemblies, dismantled, decontaminated and refurbished for underwater decontamination and size reduction operations.

\subsection{Removal of Spent Nuclear Fuel Assemblias}

When WVNS became the DOE prime contractor for the WVDP in 1981, there were $750 \mathrm{SNF}$. assemblies in the FRS storage pool. In response to the U.S. District Court order of October.1983, activities were initiated at WVDP to remove these SNF assemblies. By the end of 1986, all 625 utility owned SNF assemblies had been successfully returned to their owners, and the remaining. 125 under DOE control are waiting for NRC certification of special shipping casks to be shipped to their next destination. These 125 SNF assemblies are still being stored in the FRS pool.

\subsection{Rod Consolidation Demonstration}

A rod consolidation demonstration with PWR type SNF assemblies was conducted by personnel from Nuclear Assurance Corporation and WVNS 
at the WVDP. The rod consolidation demonstration involved six SNF assemblies with all fuel rods being removed from those assemblies. In general, the rod pulling proceeded smoothly. The highest compaction ratio attained was $1.8: 1$. Among the total of 1074 fuel rods pulled, there were some known degraded rods with collapsed cladding, (a result of in-reactor fuel densification); but no rods were broken or dropped during the demonstration.

\subsection{ERS Dismantlement}

In the FRS pool, each SNF assembly was placed in a standard canister, and rows of these canisters wer'e jupported of $f$ the pool bottom on canister racks. For FRS use in supporting the HLW solidification program, these canisters and racks must be removed from the pool. This part of the FRS dismantlement was started in early 1985 and is still in progress. It was underway during the SNF assemblies shipout campaigns. At times the rod consolidation demonstration was also conducted in parallel wilh FRS dismantlement and the SNF assemblies shipout campalgns.

\subsection{Future Volume Reduction in FRS}

After completion of the FRS dismantlement, it will be equipped for underwater handling, cutting, and decontamination operations. Radiologically contaminated vessels, tanks, and other large volume equipment, have been and will be removed from other areas of the WVDP during decontamination, dismantlement, and decommissioning operations. Some of these are now in temporary shlelded storage. These large'contaminated volumes will be size-reduced and sune of them decontaminated prior to disposal. This will simplify and economize disposal operations. 


\subsection{DESCRIPTION}

\subsection{WVDP Site and Plant}

The process plant, which is the largest building on the 1335 ha (3,300-acre) West Valley Site, has over $3.8324 E+04 \mathrm{~m}^{3}(1,353,000$ cubic feet) of volume on six elevations, five above grade and one below grade. There are 235 area divisions in this building, including the FRS, 24 shielded cells of various sizes, several laboratories, and several other auxiliary areas. Figure 1 shows where the more important areas are located in the plant.

\subsection{Fuel Receiving and Storage Facility (FRS)}

The SNF assemblies have been stored underwater in the FRS fuel storage pool. The concept of underwater storage of SNF assemblies is relatively simple and straightforward. The water provides a sink for the removal of radioactive decay heat, shielding for the protection of facility personnel against radiation, and a transparent medium for easier handling and inspection operations.

A plan view of the FRS is given in Figure.2, and an elevation in Figure 3. As shown in these Figures, the significant areas of FRS are the Cask Unloading Pool, the Fuel Storage Pool, Cask Handling Area, and the Cask Decontamination Area.

The functional systems are: 1) fuel transfer and handling system, 2) a pool water quality and cooling system, 3) a system for treatment and containment of radwastes, and 4). a ventilation system for removing airborne radionuclides and controlling temperature and humidity. 


\subsubsection{Cask Unloading Pool}

Both the Cask Unloading Pool (CUP) and the fuel storage pool are below-grade, and constructed of reinforced concrete embedded in the silty till soil common to the West valley location. The concrete floor of the entire pool system, which is oriented in an east-west lengthwise direction, is $991 \mathrm{~mm}$ (39 inches) thick, and the outside walls are $991 \mathrm{~mm}$ (39 inches) thick. The entire pool contains about $3104 \mathrm{~m}^{3}$ ( 820,000 gallons) of demineralized water, of which $2498 \mathrm{~m}^{3}$ (660,000 gallons) are in the fuel storage pool.

The CUP is east of the fuel storage pool and is used for the removal of the SNE assemblies from the shipping cask and their placement in the fuel storage canisters or vice versa. The CUP is about $7925 \mathrm{~mm}$ (26 feet) by $7315 \mathrm{~mm}$ (24 feet) and is sectioned to depths of $8839 \mathrm{~mm}$ (29 feet) and $13.4 \mathrm{~m}$ ( $44 \mathrm{feet}$ ). The deeper section provides the $3353 \mathrm{~mm}$ (11-feet) of water shielding necessary for removal of SNF assemblies, up to $4877 \mathrm{~mm}$ (16 feet) in length, from a shipping cask sitting in a clearwell bucket on the bottom of the CUP. The shelf area, $8839 \mathrm{~mm}$ (29 feet) deep, is used for placement of the clearwell bucket for cask handling operations. The clearwcll bucket is used to eliminate contact between the cask's outer surface and the pool water. The annulus between the cask and the bucket is slightly pressurized with demineralized water to prevent pool water from contacting the cask.

The CuP area is lined with stainless steel, $2 \mathrm{~mm}$ thick ( 14 gauge) on the walls and $5 \mathrm{~mm}$ ( $3 / 16$ inches) on the floor to facilitate decontamination of the area. The space between the CUP liner and the concrete wall is equipped with both a leak detection and a collection-retur n system. 
A $3048 \mathrm{~mm}$ (10 foot) square table $3353 \mathrm{~mm}$ (11 feet) high is located in the northeast corner of the shelf area. This table provides for elevation of the clearwell bucket such that the top of the bucket is approximately. $152 \mathrm{~mm}$ (one-half foot) above the waterline. There is a removable watertight gate which serves to isolate the CUP from the storage area so that the CUP can be drained without draining the pool. A rack on the north wall provides for storage of the gate.

\subsubsection{Storage Pool}

The fuel storage pool measures $22.86 \mathrm{~m}$ (75 feet) by $12.19 \mathrm{~m}$ ( 40 feet) by $8837 \mathrm{~mm}$ ( $29 \mathrm{feet}$ ) deep and is filled with demineralized water to a depth of $8534 \mathrm{~mm}$ (28 feet). The concrete basin sits in the impermeable silty till of the west valley site and analysis has shown that the pool will survive the Safe Shutdown Earthquake (intensity VII-VIII) with. epicenter $37 \mathrm{~km}$ ( $23 \mathrm{miles}$ ) from site. The fuel storage racks consist. of an aluminum beam structure with 42 storage rows oriented north-south, providing a total capacity for 924 fuel storage canisters. Each row will accommodate up to 22 canisters, but normally only 21 are stored in a-row for operating convenience.

The racks are fastened on the north wall and to the bottom of the pool. There is a $1219 \mathrm{~mm}$ (4-foot) wide aisle between the south end of the racks and the pool. wall to allow movement of the canisters. When the canisters are emplaced on storage racks, there is a minimum of $3353 \mathrm{~mm}$ (11 feet) of water shielding above the $\mathrm{SNF}$ assemblies as shown in Figure 4. The racks and canisters in their storage configuration provide $514 \mathrm{~mm}$ (20.25 inches) center-to-center spacing and at least $192 \mathrm{~mm}$ ( 7.55 inches) edge-to-edge distance between canister tubes in the same row. Between rows the spacing is $508 \mathrm{~mm}$ (21.0 inches) center-to-center and $190 \mathrm{~mm}$ ( 7.5 inches) minimum edge-to-edge. The racks have also been analyzed and found to withstand the Safe Shutdown Earthquake. 
The canisters consist of $6.35 \mathrm{~mm}(1 / 4$ inch) aluminum tubes $317.5 \mathrm{~mm}$ (12.5'inches) I.D. with a spacer and pickup ring on the top, a support $r i n g$ in the center, and a spacer in the bottom to insure $514 \mathrm{~mm}$ (20.25 inches) center-to-center spacing. The canisters can hold SNF assemblies as large as $4877 \mathrm{~mm}$ ( $16 \mathrm{feet}$ ) in length and about $222 \mathrm{~mm}$ ( 8.75 inches) in cross section. One PWR type SNF assembly and up two or three or the small BWR type SNF assemblies can be stored in each canister (subject to criticality considerations and licensing approval). Assuming one large PWR SNF assembly (equivalent to $0.45 \mathrm{MTU}$ ) per canister, the present maximum storage capacity of the pool without reracking is 416 MTU.

\subsection{ERS Equipment}

Cask and fuel handling equipment in the FRS includes a $90.7 \mathrm{Mg}$ (100ton) crane with two $4536 \mathrm{~kg}$ (5-t.on) aluxiliary holsts, cask lifting yokes, a cask decontamination stall with a high pressure water spray system, a clearwell bucket and clearwell huckét. 1 ifring yoka, a sask. lid ball and grapple, assorted fuel graphles, the rilp service bridge, a $907.2 \mathrm{~kg}$ (1-ton) fuel crane, fuel storage canisters, a canister 1 ift rack, a canister bridge and a canister crane.

\subsubsection{The $90.7 \mathrm{Mg}(100-$ Ton) Cask Crane}

The cask crane shown in Figure 5 is mounted on a high bridge running cant-wegt of the wast orid of hie $F R$ and ocrvices the cask receiving area, decontamination stall, and the CUP. The crane has a north-south trolley mounted $90.7 \mathrm{Mg}$ (100-ton) hoist and two smaller trolley-mounted $4536 \mathrm{~kg}$ (5-ton) hoists also moving in a north-south direction. The $90.7 \mathrm{Mg}$ (100ton) bridge hoist cannot extend over the fuel storage pool which has a lower roof line. There is no way that this hoist can drop anything on the stored SNF assemblies. Redundant 
rigging is therefore not required for crane operations with this pool configuration. The total lift available is approximately $25.9 \mathrm{~m}$ ( $85 \mathrm{feet}$ ), of which $11.6 \mathrm{~m}$ (38 feet) is above the floor of the cask transport unloading area.

The crane is normally operated from a remote hand held control box but also has a pendant control. Each movement of the $90.7 \mathrm{Mg}$ (100-ton) crane has 5-step variable speed in either direction. The $4536 \mathrm{~kg}(5$-ton) hoists have two speed motions.

When the proper lever switches on the transmitter of the remote radio control are manipulated, the operator can perform the same operations that he can with the pendant controls, but with greater ease and flexibility. Before any crane motors can operate, the POWER ON, MAIN ON, and at least one function switch on the console must be energized simultaneously. This built-in safety feature virtually precludes accidental or unintentional operation of the crane. If the radio control system should be inoperative, the crane can be used in the pendant mode by operating the manual controls.

Each day the crane is in operation, the following inspections are required:

(1) Check function of hoist up limit-switch under no load at beginning of each shift crane is used.

(2) Check all other functional operating mechanisms.

(3) Visually inspect crane load block hooks for cracks or deformation.

(1) Visually inepect lifting yokes for cracks, twisto and wear. 

(5) Visually inspect slings and crane cable for kinks, fraying, and cut wires.

\subsubsection{Cask Lifting Yoke}

The cask 1 ifting yoke is usually unique for each cask or cask type and enables the crane hook to lift the cask by its two trunnions. The cask lifting yoke is supplied by the cask vendor and usually travels with lhe cask fur use at both t.he reactor pool and the FRS. Lifting yokes and cask handling gear do not come in contart. with the posl water, and, henoe, do not normally become contaminated.

\subsubsection{Decontamination Stall}

The decontamination stall, is a curbed stall about $4267 \mathrm{~mm}$ (14 feet) on a side and $8992 \mathrm{~mm}$ (29 1/2 feet) high, of stainless steel and aluminum construction. The stall is equipped with a sliding door and roof to permit the $90.7 \mathrm{Mg}$ (100-ton) crane to position a cask vertically inside. The platform also permits positioning personnel, at all levels on the cask for radiation surveying and hand decontamination, if necessary. The stall is equipped with a donut shaped elevator-type platform which facilitates cask preparation for CUP operations and for shipping preparation. The platform is equipped with an oscillating $18614 \mathrm{k} \mathrm{Pa}$. (2700 psi) high pressure water spray ring that is used for decontamination.

\subsubsection{Cask Washdown System}

The high pressure water system for cask washdown consists of a diesel driven pump enclosed in a small building adjacent to the east wall of the FRS, piping, and spray nozzles in the decontamination stall. The pump and engine are capable of 
delivering $18614 \mathrm{k} \mathrm{Pa}$ (2700 psig) at a flow of $353 \mathrm{E}-05 \mathrm{~m}^{3} / \mathrm{s}$ (56 g pm) but are normally used at a $13788 \mathrm{k} \cdot \mathrm{Pa}(2000 \mathrm{psig})$ and $353 \mathrm{E}-05 . \mathrm{m} / \mathrm{s}$ ( $56 \mathrm{gpm}$ ) output. The spray ring for the cask body has eight solid cone spray nozzles which will deliver 44 E-05 $\mathrm{m}^{3} / \mathrm{s}(7.0 \mathrm{gpm})$ each at $13788 \mathrm{k} \mathrm{Pa}(2000 \mathrm{psig})$. The body spray ring is connected to the water supply through a heavy duty flexible hose and also rotates back and forth in a horizontal plane $15^{\circ}$ to cover all areas of the cask. A second $f i x e d$ low pressure spray ring with eight nozzles is provided to cover the bottom end of the cask. This ring operates a $1379 \mathrm{k} \mathrm{Pa}$ (200 psig) and $315 \mathrm{E}-05 \mathrm{~m}^{3} / \mathrm{s}$ (50 g pm). Both demineralized and plant utility water can be used in the system and pressure is controlled by a by pass valve and engine RPM.

\subsubsection{Decontamination Stall Ventilation System}

A $203 \mathrm{~mm}$ ( 8 -inch) duct at the top of the decontamination'stall is capable of drawing of $f$ up to $4719 \mathrm{E}-04 \mathrm{~m}^{3} / \mathrm{s}(1000 \mathrm{cfm})^{-}(10$ air changes per hour) from the stall interior when it is in use. This air is ducted to the main ventilation washer in the reprocessing plant and from there to the main exhaust filters and plant stack.

\subsubsection{Clearwell Bucket and Lifting Yoke}

The clearwell bucket is used in the CUP and serves to isolate casks from CUP water. The bucket is cylindrical and measures $135.5 \mathrm{~mm}$ ( 5 feet 4 inches) I.D. by $5334 \mathrm{~mm}$ ( 17 feet 6 inches) high. It was designed to accommodate the NFS-4 cask. A specially designed Iid seals the opening between the top of the bucket and the top of the cask to prevent contaminated 
CUP water from contacting the outside of the cask. The lid is lifted by means of a hand operated jack screw device and swings aside to permit insertion or removal of a cask. The annular space between the cask and bucket is filled with clean demineralized water and kept pressurized when the device is sealed by means of a $0.98 \mathrm{~m}^{3}$ (260 gallon) head pot located about $1524 \mathrm{~mm}$ ( 5 feet) above the bucket and connected through a rubber hose to the bucket. The water in the bucket, is sampled after each use and is replaced if its aotivity is over $3.7 \mathrm{E}+06 \mathrm{~Bq} / \mathrm{ml}\left(1 \times 10^{-4} \mu \mathrm{Ci} / \mathrm{ml}\right)$.

The clearwell bucket is positioned on a platform on the $8839 \mathrm{~mm}$ (29-foot) level of the CUP for cask insertion or removal and is lowered to the $13.4 \mathrm{~m}$ (44-foot) level for fuel removal. Movement. of the bucket and aas $k$ is done through a lifting yoke and the $90.7 \mathrm{Mg}(100-t o n)$ crane. Use of the clearwell bucket in conjunction with the Decontamination Stall makes a more rapid cask turn-around possible by reducing decontamination time for the cask exterior after it has been loaded. The clearwell bucket also minimizes the phenomene of contamination leaching out of the cask surface with time (see section 7.4.7).

A special 1 ifting strongback attaches to two trunnions on the clearwell bucket is used by the $90.7 \mathrm{Mg}$ (100-ton) crane to lift or lower the busket. het.wen the $8839 \mathrm{~mm}$ and $13.1 \mathrm{~m}$ (20) and 44 foot) levels of the CUP. This lifting strongback is stored on a rack on the CUP wall when not in use and saves having to immerse the crane hook, block, and cable into the contaminated CUP water so that when the cask is 1 if ted out of the clearwell bucket there is no dripping of CuP water on the f'loor and the cask exterior. 
The TN-9 shipping cask used in the recent SNF assembly

removal campaigns uses a vinyl cover instead of the clearwell

bucket as described in Section 7.3.3.

\subsubsection{Cask Lid Spider.}

A lifting bail or spider is bolted to the cask lid exterior before it is lowered into the CUP and the lid bolts are removed so that when the cask is at the $13.4 \mathrm{~m}$ ( $44 \mathrm{foot}$ ) level the lid can be removed. One of the $4536 \mathrm{~kg}$ (5-ton) hooks with a long grapple is used for this task. The grapple keeps the crane hook dry as with the bucket lifting yoke. The lid can be either set on the $8839 \mathrm{~mm}$ (29 foot) level shelf or removed from the CUP for temporary storage and if required, hosed down and decontaminated.

\subsubsection{Fuel Grapples}

Various long handled grappling tools are used to engage the fuel elements and $l$ ift them free of the cask. These grapples are usually specific for each fuel type and again also serve to keep the hoist parts free of the CUP water. The grapples are stored on racks in the CUP when not in use to eliminate the spread of contaminated pool water. They can be removed and decontaminated for repair or adjustment.

\subsubsection{CUP Service Bridge}

The CUP service bridge spans the width of the storage pool and runs east-west on rails mounted on the tops of the north and south pool walls. The bridge has a walkway with hand rails suitable for personnel to work from it, and is motorized with the controls on the bridge rail. A fuel hoist is mounted on the CUP service bridge and movement of fuel in the CUP is performed from the bridge. The CUP service bridge 
does not normally run out over the storage pool because of interference between the hoist boom and the lower roof line over the pool. The feet per minute travel, at two speeds $61 \mathrm{E}-03$ and $254 \mathrm{E}-03 \mathrm{~m} / \mathrm{s}$ ( 12 and 50 feet per minute), is restricted by limit switches. The hoist boom can be demounted if the CUP bridge is needed over the storage pool.

\subsubsection{Fuel Hoist}

A small $907 \mathrm{~kg}$ (1-ton) electrically driven hoist is mounted on the CuP service bridge and is controlled from that polnt. The fuel hoist, in combination with a grapple, serves to lift SNF assemblies from casks in the CUP and lower it into storage canister's or to reverse this procedure for placing the. SNF assemblies into casks. Hoisting speed is $7.6 \mathrm{E}-03 \mathrm{~m} / \mathrm{s}(1-1 / 2$ feet per minute). Limit switches prevent overload, and with the hoist elevation limit and the grapple length configurations keep the $3353 \mathrm{~mm}$ (11 feet) of water shielding required by the Technical Specification.

\subsubsection{Canister Lift Rack}

The canister lift rack is mounted on the west wall of the CUP and can hold up. to four fuel canisters in a straight row oriented north-south. The rack has a vertical travel of $4851 \mathrm{~mm}$ ( 15 feet 11 inches) and is moved by means of an electric hoist. At the lower end of the rack travel the bottom of the canisters are at the $13.4 \mathrm{~m}$ ( 44 foot) depth in a position to receive fuel removed from a cask with the fuel hoist. When the rack is raised.to its upper level, the tops of the canisters are at the same level as when they rest on the storage racks and are available to be picked up with the canister crane. A mechanical stop prevents the rack from being raised to a height that would reduce shielding to less than $3353 \mathrm{~mm}$ ( 11 f eet). 


\subsubsection{Fuel Storage Pool Bridge}

The fuel storage pool bridge shown in Figure 6 is similar to the CUP service bridge and is positioned west of the CUP bridge on the same set of rails so that it can travel the full east-west length of the storage pool and part way over the CUP. The bridge has a work platform and hand rails and has the canister crane mounted on it. Operation is from a control box on the bridge and there are two east-west speeds of $30.5 \mathrm{E}-03$ and $127 \mathrm{E}-03 \mathrm{~m} / \mathrm{s}$ ( 6 and 25 feet per minute) plus an inching speed of $2.54 \mathrm{E}-03 \mathrm{~m} / \mathrm{s}$ ( 6 inches per minute).

\subsubsection{Canister Crane}

The canister crane is mounted on the fuel storage pool bridge shown in Figure 3 and is used to 1 ift canisters and move them in a north-south direction in the racks (last in first out) or in the CUP. East-west movement is accomplished by the fuel storage pool bridge. The canister crane has a $1814 \mathrm{~kg}$ (2-ton) capacity and a hoist speed of $10.2 \mathrm{E}-03 \mathrm{~m} / \mathrm{s}$ ( 2 feet per minute). The vertical travel is limited to $133 \mathrm{~mm}$ (5-1/4 inches) in the "locked" position and $337 \mathrm{~mm}(13-1 / 4$ inches) in the "unlocked" position. Travel speed of the north-south trolley is 30.5 E-03 and 127 E-03 m/s ( 6 and 25 feet per minute) and an inching speed of $2.54 \mathrm{E}-03 \mathrm{~m} / \mathrm{s}$ ( 6 inches per minute). The canisters are lif ted by means of a grapple on the end of the canister hoist boom which extends vertically downward from the bridge trolley. The grapple is positioned over the center of the fuel canister by movement of the bridge and trolley. There are indexes for each canister location to locate the crane trolley and bridge. The grapple is lowered into position using the crarle. The operating handie is manualdy turned clockwise to engage the canister for pickup. The grapple is 
raised $133 \mathrm{~mm}$ (5-1/4 inches) and the canister is ready to be transported. After the canister is moved to the designated location, a reverse procedure is used to disengage the grapple from the canister.

Limit switches on the bridge prevent damage to the bridge and motor. They will stop the drive motor before the bridge contacts the CUP service bridge or the end of the tracks. Limit switches on the trolley stop the drive motor when the trolley approaches either end of the bridge.

There are seven limit switches restricting travel of the grapple hoist mechanism. The grapple lower position restricts the downward movement of the grapple in either the pickup or release mode. The grapple upper/pickup position restricts the upward movement of the grapple and canister so that the SNF assembly will not be raised to an unsafe level in the pont. The grapple upper/released pesition switch restricts upward movement of the grapple but allows it to raise high enough to clear fuel assemblies protruding from the canisters in the storrage ranks. The hoist. arm has fnur directional limit switches, any of which will turn of $f$ the bridge drive motor if the hoist arm contacts an obstruction while traveling in any. of the directions.

\subsubsection{Swing Arm}

The swing armis located at the southwest.corner of the storage pool and was used during reprocessing to move a single canister and its contained fuel from a pickup position where it receives the canister from the canister hoist on the fuel storage pool bridge to an input position where the $f$ uel can be hoisted inside the Process Mechanical Cell (PMC) through a trapdoor in the southeast corner of the cell. A reverse movement can be made where any object up to 


\begin{abstract}
$4877 \mathrm{~mm}$ ( $16 \mathrm{feet}$ ) long and $304.8 \mathrm{~mm}$ (one foot) diameter can be lowered into a canister from the PMC to be moved into the storage pool. The rated capacity of the swing arm is 1814 $\mathrm{kg}$ (two tons). The swing arm, while still operable, has not been used since plant reprocessing operations. It probably will be used in the future to remove material from the Process Mechanical Cell.
\end{abstract}

\title{
3.4 FRS Pool water Treatment System
}

The FRS pool water treatment system is required to maintain the purity of the water in the pool. This system consists of a filter precoat tank, heat exchanger, circulator pump, leaf filter and ion exchanger. A new high integrity container (HIC) spent resin handling subsystems was recently added. During operation of the fuel pool water system, water from the surface of the pool is withdrawn via a weir to a $3154 \mathrm{E}-05 \mathrm{~m}^{3} / \mathrm{s}(500 \mathrm{gpm})$ recirculating pump which pumps the water through a leaf filter and returns it to various areas of the pool. A side stream may be sent to either the pool ion exchanger and/or the pool cooler.

\subsection{FRS Ventilation System}

Heat energy released from the SNF assemblies in the FRS pool to the surrounding water raised the temperature of the pool water. The pool water cooling system controlled the water temperature at approximately $12.4^{\circ} \mathrm{C}\left(80^{\circ} \mathrm{F}\right)$ but less than $29.1^{\circ} \mathrm{C}\left(110^{\circ} \mathrm{F}\right)$. Since the decay heat from the SNF assemblies remaining in the pool is so $1,0 w$, pool water cooling has not been required for the past few years. In this temperature range, the vaporization rate of the water, combined with the large surface area of the pool, significantly increased the moisture content of the FRS air. Air being circulated through the FRS ventilation system is dehumidified by cooling to reduce the moisturc content, reheated to reduce the relative humisit.y, and then filtered to remove airborne particulate before being recirculated 
back to the FRS. Filtering consists of a prefilter stage and a HEPA filter stage installed in a special filter housing system. After filtering, the dehumidified and filtered air is mixed with makeup air, reheated as required and recirculated. The recycled air is distributed to the FRS along the south side of the pool and removed from the north side of the pool to provide a ventilation rate of approximately nine air changes per hour above the pool area.

A1r in excess of that being recirculated which is about 23595 E-0 5 $\mathrm{m}^{3} \mathrm{~s}(5,000 \mathrm{cfm})$ is continually exhausted from the general area through a louver on the west end of the south wall of the FRS into the existing main ventilation system and discharged directly to the exhaust plenum of the $609.6 \mathrm{~m}$ ( 200 foot) plant stack. A continuous exhaust from the decon stall enclosure and a waste drumming station pass through existing ductwork to the ventilation. wash cell. Then is is filtered before passing to the plant stack.

\subsection{FRS Security.}

The FRS is classified as a security area. This requires security protection in compliance with the WVDP Safeguards and Security Plan (latest revision).

Access is controlled by the security force at all entrances and egress points. Entrance to this security area requires passage through at least two physical barriers. The first physical barrier at the perimeter is separated from the second physical barrier and the intervening space denoted as an isolation zone, is monltured periodically by the security force. The isolation zone is illuminated during hours of darkness to certain specifications. The security area is controlled by an active intrusion alarm system.

\subsection{FRS Accountability}

For accountability. purposes, the FRS is designated as a Material 
Control Area, and Material Balance Area. Accountability in the FRS is a two-fold process. First is the accountability operators in the FRS. The second is accountability by the Accountability

Representative in the office. Their duties, although similar, serve as a check and balance on one another.

\subsubsection{Accountability by Operators}

The movement and shipment of $f$ uel is authorized by a Letter of Nuthorisation (LOA). A LOA cunsisls of:

- Identification of the utility owner

- Fuel assembly serial number

- Authorization to move fuel for specific purposes

- Identification of shipping cask to be used

- Uperating procedures to be used

A Fuel Movement Directive (FMD) is used to control the specific, individual fuel moves necessary to accomplish the purposes identified in the LOA.

The operators maintain a status board which is a pool grid map. To identify a pool storage position which contains a storage canister a green status card is inserted in the corresponding position. The card contalns the storage canister ID number, what spacer (adjusts for differences of. fuel assembly length in relation to top of storage canister) and if a spider (used to center assembly in storage canister) is installed in the canister. Should a storage canister contain a SNF assembly. an additional color coded card is inserted in the corresponding position. A white card 
signifies normal handling of a fuel assembly. A gold card signifies that special handling of the fuel assembly is required. The card for a fuel assembly contains the following information:

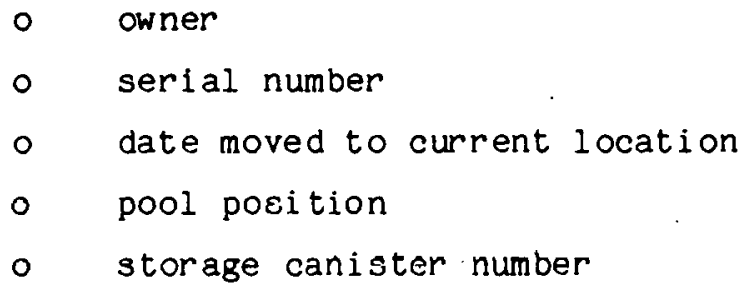

The gold card will contain the above information and an indication of the special handling required.

Each fuel movement whether it be from storage position to storage position or from storage position to a shipping cask is documented in writing. This documentation is submitted to the Accountability Representative.

\subsubsection{Accountability by the Accountability Representative}

The Accountability Representative (AR) is responsible for the accounting of SNF assemblies "accountable" special nuclear máterial, as requlred by NRC/DOE iegulations. Thio io donc in a double entry bookkeeping system. A receipt/shipment account is kept for each util,it.y. A receipt/shipment account is kept for the FRS.

The AR maintains a second pool map with the documentation prepared by the FRS operators. This map is used to determine the fuel shipping scheme or what pool shuffling must be done to ship a specific SNF assembly. The AR performs a physical inventory of the SNF assemblies on a semi-annual basis. The physical inventory is performed by identifying what type (utility) of fuel resides in which pool position.. This 
physical inventory is checked against the FRS pool map, and the AR's pool map. The AR's pool map is checked against $E R S$ pool map. Any discrepancies are resolved. The AR prepares all documentation and reports required for the accountability of special nuclear material. 


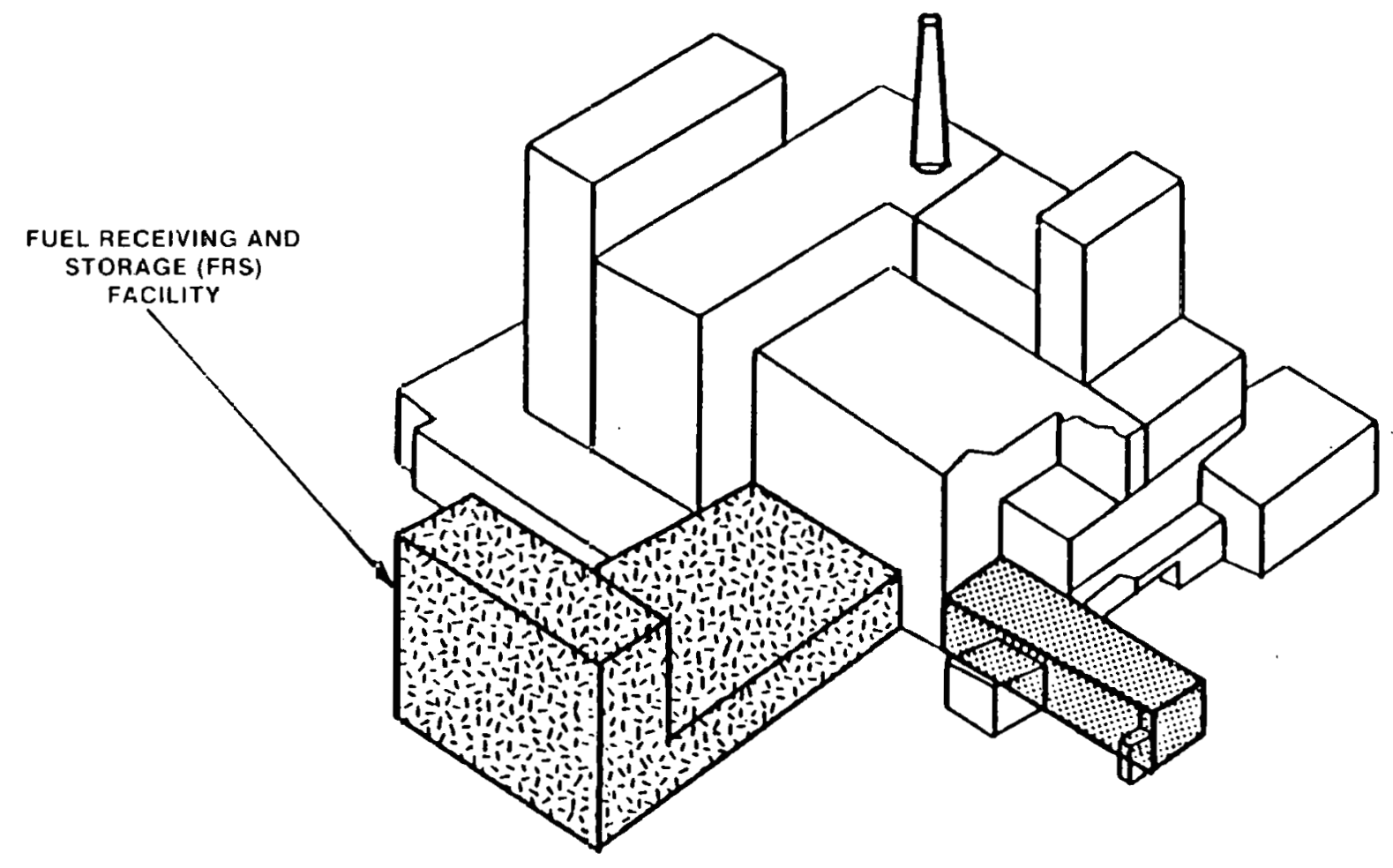

FIGURE 1

Plant-Identifying Fuel Receiving and Storage Facility Location 


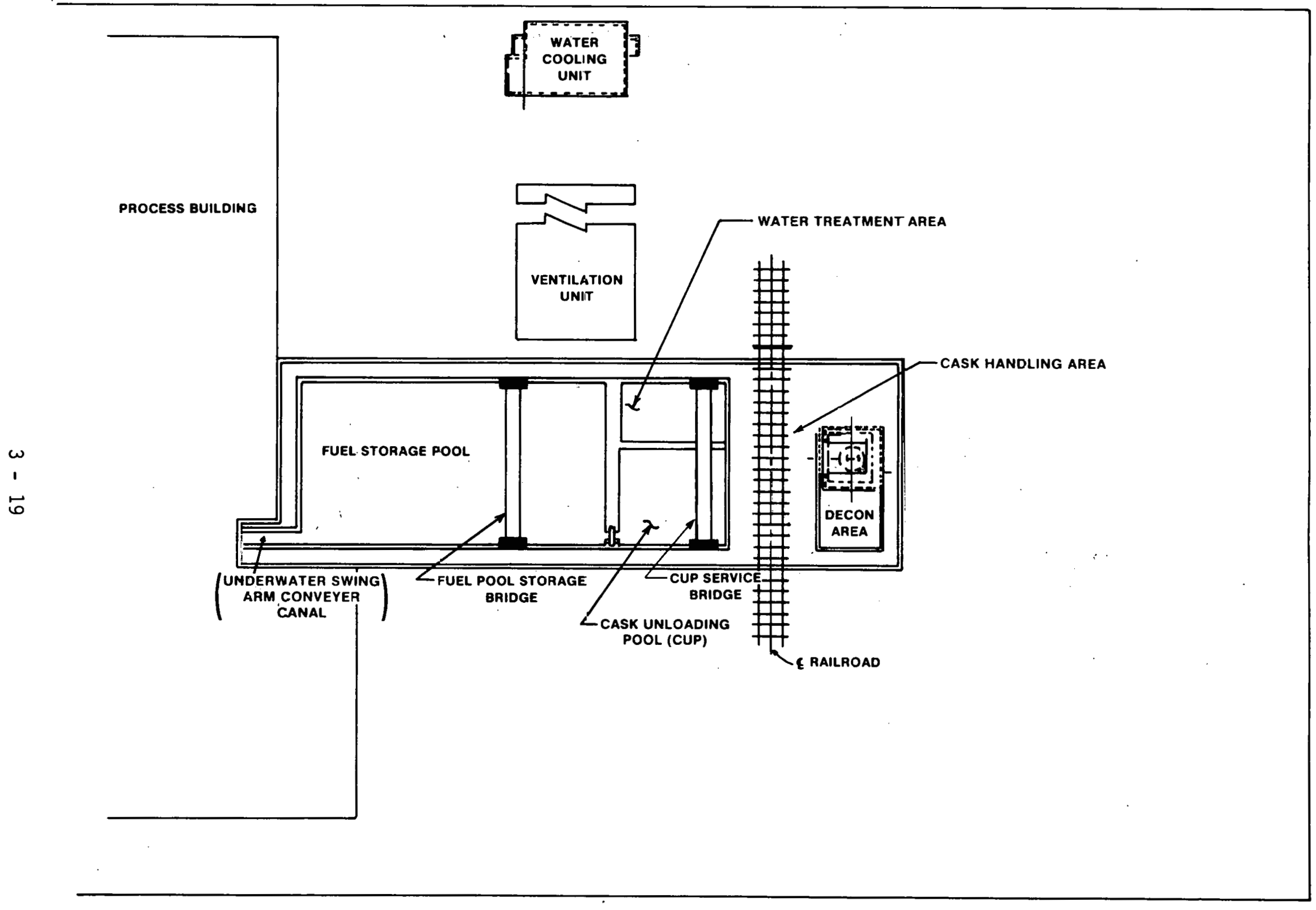

FIGURE 2

West Valley Fuel Receiving and Storage, Plan 


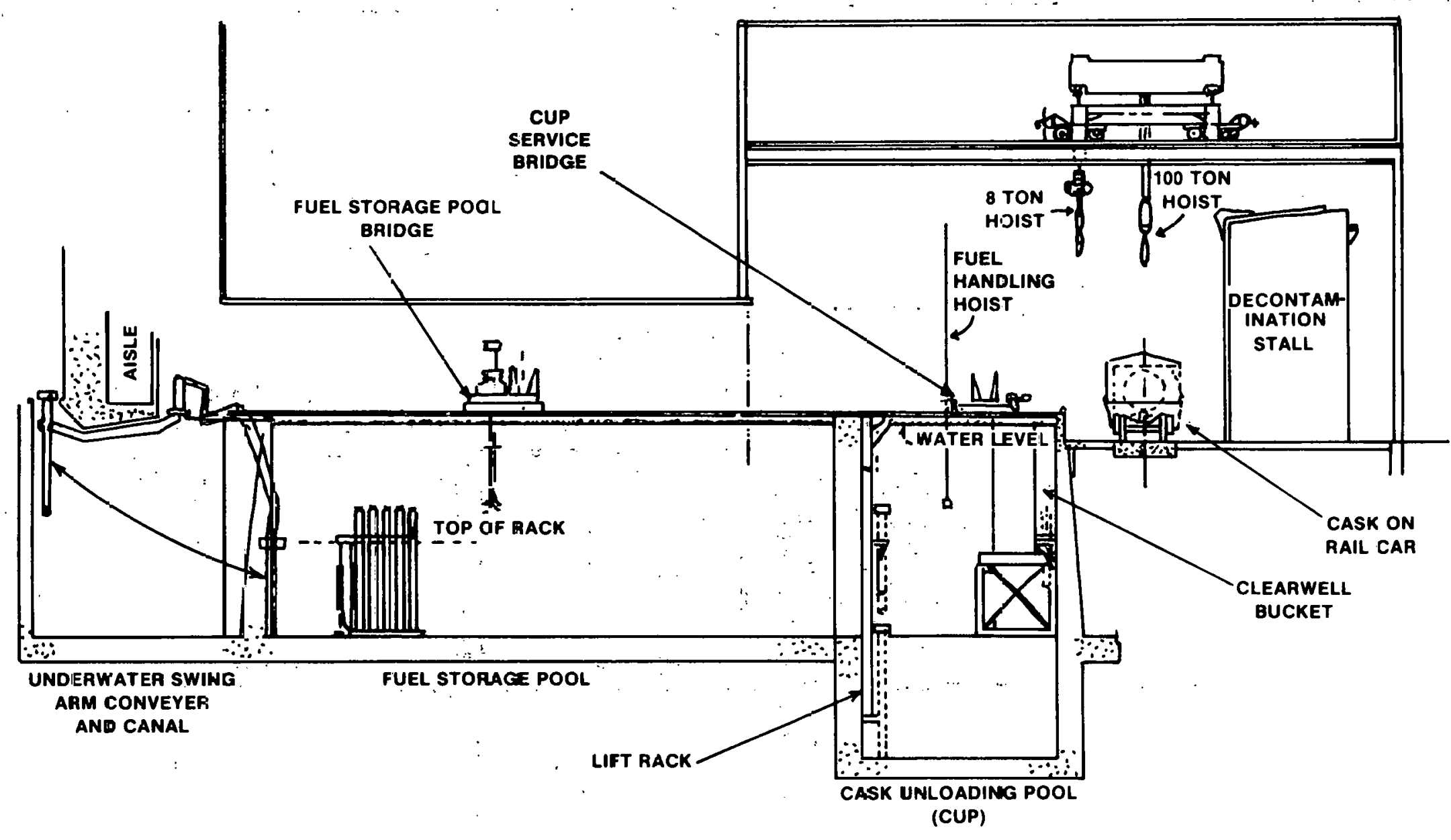




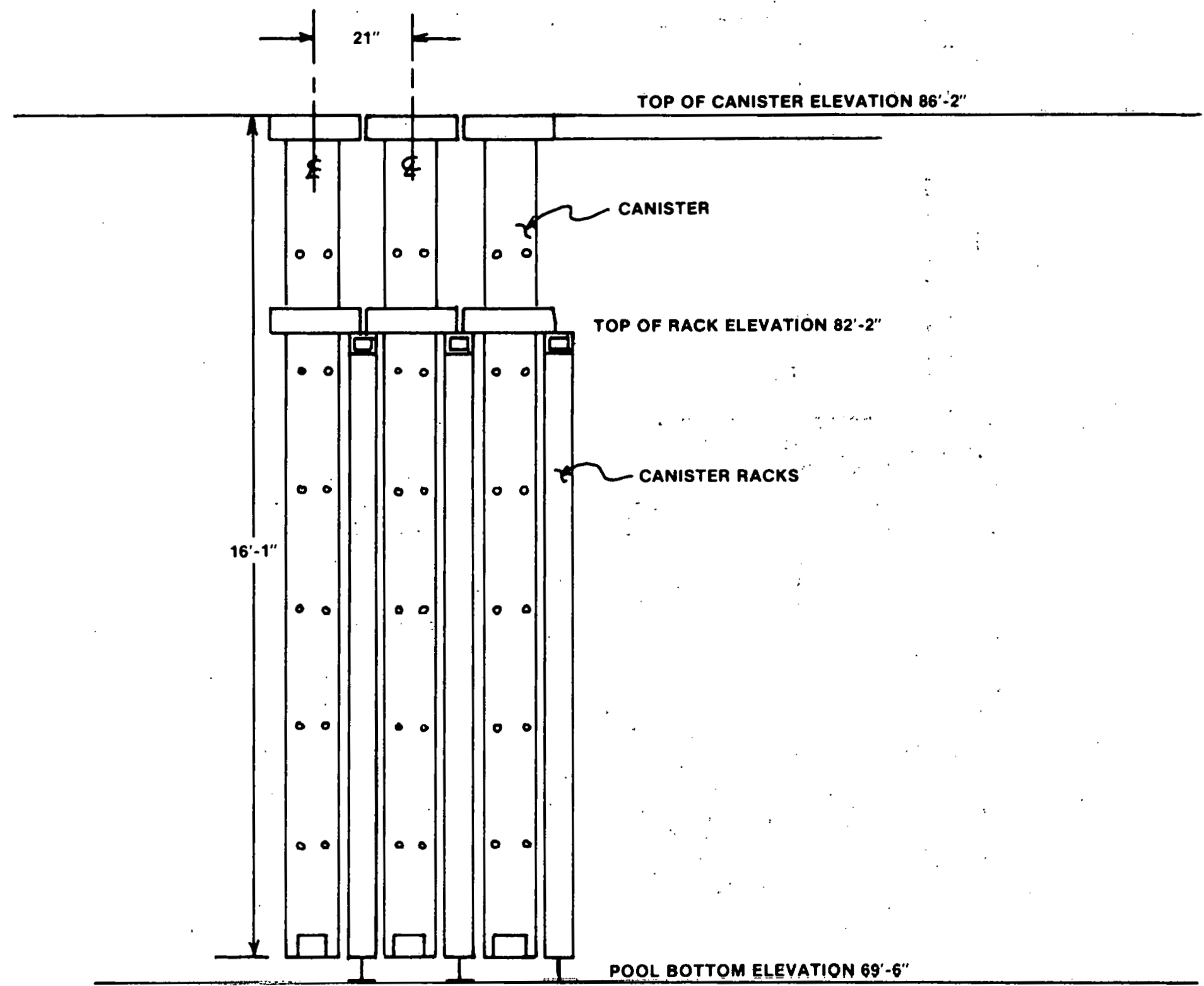

\section{FIGURE 4}

Storage Racks with Canisters 


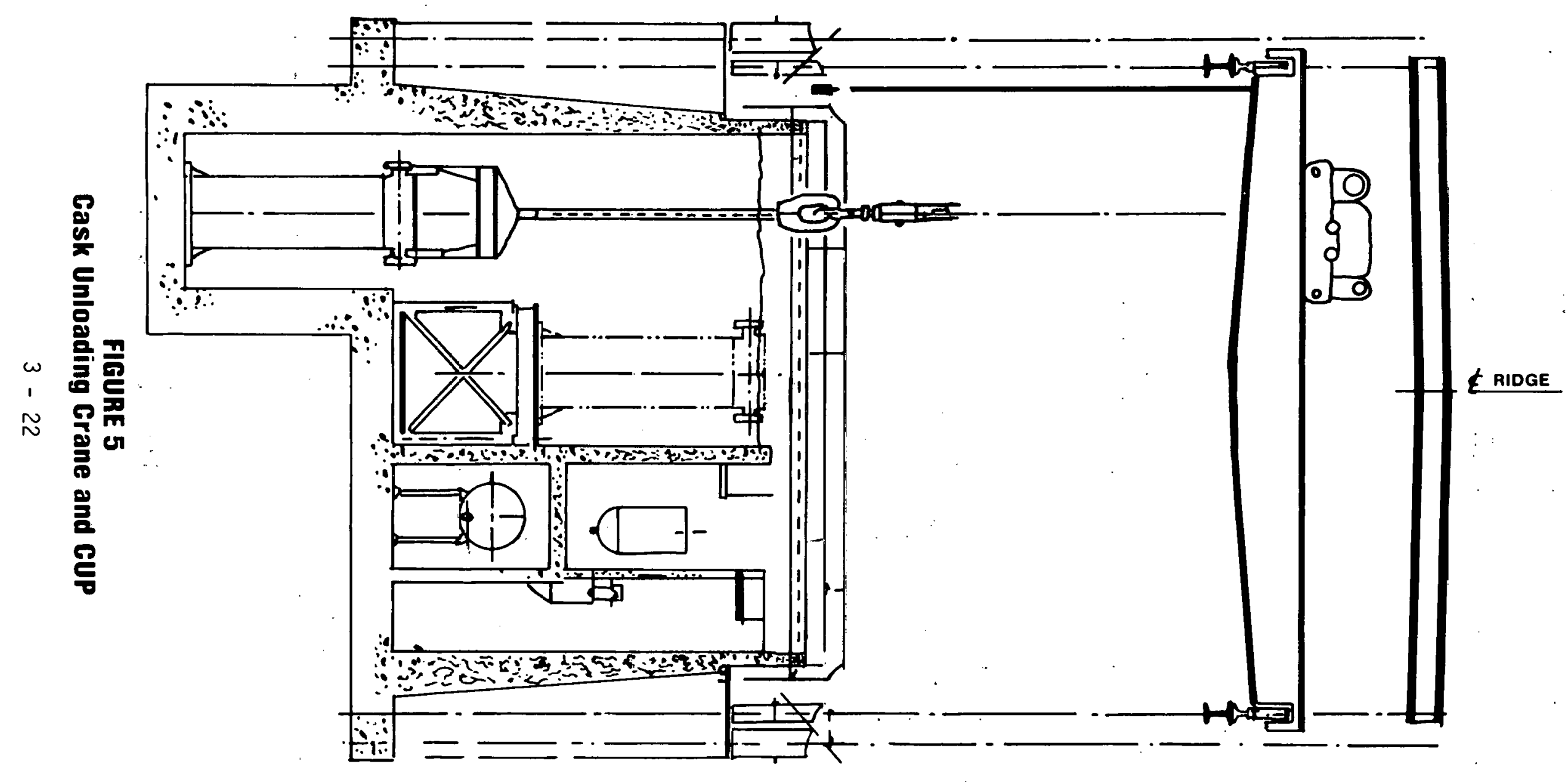




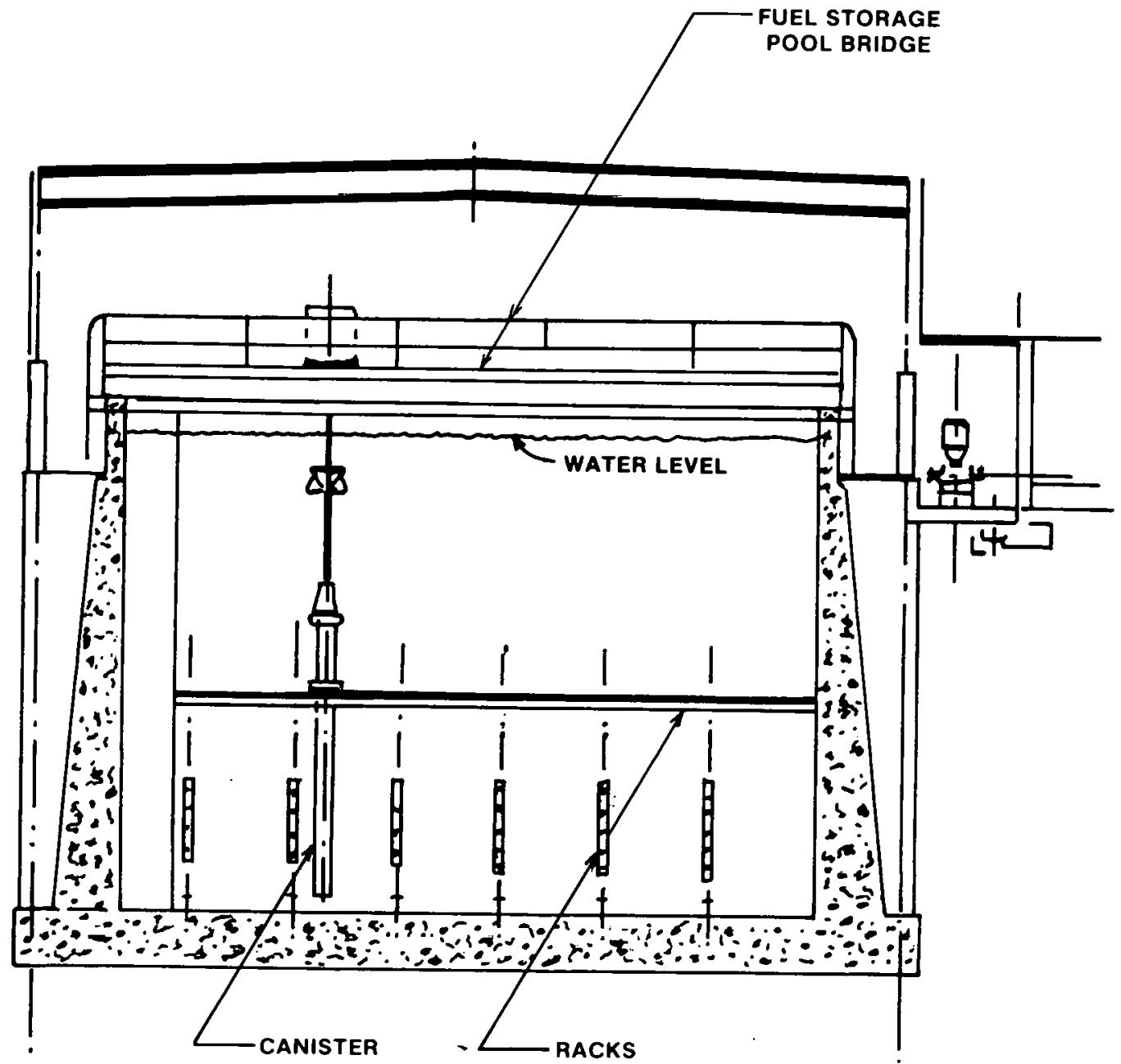

FIGURE 6

Fuel Storage Pool Bridge 


\subsection{CASK HANDL ING AND UNLOADING PROCE DURES}

The handling and unloading of spent fuel shipping casks, which took place prior to the WVDP, was essentially a three-phase operation commencing with a), the receipt of the cask on site and preliminary preparation; proceeding with $b$ ), 'transfer of the fuel from the cask to the fuel storage canister; and culminating with c), the removal of the empty cask from the CUP, decontamination, and replacement on the transport vehicle (truck or rail) for return shipment.

One hundred and fifty-two MTU of fuel stored in the FRS were shipped in NFS-4 casks. : The remaining $11 \mathrm{MTU}$ of the $1.75 \mathrm{MTU}$ of fuel were shipped in NFS-X2 casks. Figure 7 is a photograph of these two casks.

\subsection{Recelving and Preparation for Unloading}

When a fuel shipping cask arrived at the plant, the security personnel immediately notified the Operations Shift Supervisor and a Radiation and Safety ( $R / S)$ representative.. If the associated shipping forms were in order, the tractor and trailer were moved to the FRS. No cask work was permitted unt1l:an R/S survey was completed:

Inside the FRS the cask containing the SNF assembly(ies) was removed from its truck (or rail car) using the $90.7 \mathrm{Mg}$ (100-ton) FRS Crane as shown in Figure 8. The cask was then moved into the decontamination stall as illustrated in Figure 9.

In the decontamination stall, cask coolant pressure and temperat ure checks were made, and the cask inspected and prepped for pool handl ing .

The cask was decontaminated with pressurized water spray with demineralized water. The cask was then transferred to the clearwell bucket. in the Cask Unloading Pool. 


\subsection{Fuel Transfer}

With the clearwell bucket 1 id raised and rotated to the side, the cask was lowered into the bucket as illustrated in Figure 10. After its if was installed, the clearwell bucket was filled with deminerallzed water, and transferred to a predetermined location on the FRS CUP floor (13.4 m (44 foot)) level.. The cask 1 id was removed with a grapple and the $4536 \mathrm{~kg}$ ( 5 ton) on the cask crane. The one ton fuel holst, located on the CUP service bridge, transferred the SNF assembly from the shipping cask to an empty fuel storage canister on the lift rack in its lowered position. The canister containing the SNF assembly was then moved to its predetermined position in the FRS pool and placed on the canister rack in the pool. Figure 11 shows the SNF assemblies in their canisters which are supported on the racks under 11 feet of water in the FRS storage pool.

When the SNF assembly had been removed, the clearwell bucket containing the empty cask was lifted and placed on the table on the CUP upper ( $8839 \mathrm{~mm}(29-f \circ o t))$ shelf where the bucket lifting yoke was removed. The water was pumped from the cask cavity to lite puul overflow weir. The decontaminated cask 11d, with gaskets in place, was assembled to the cask, and the lid lifting bail removed.

\subsection{Removal from CUP and Preparation for Return Shipment}

The cask lifting yoke was attached to the cask and the empty cask was transferred from the clearwell bucket to the decontamination stall for shipping preparations. The cask cavity was pressurized with air to $68.9 \mathrm{k} \mathrm{Pa}$ to $103.4 \mathrm{k} \mathrm{Pa}(10-15 \mathrm{psig})$ via the vent forcing the remaining water in the cask cavity to drain. If required, the cask was decontaminated in the decontamination stall. When surveys showed that cask contamination levels were 
below limits for shipment, the cask was placed on and secured to the truck trailer. After a final radiation and contamination survey, the appropriate release papers were prepared authorizing removal from the site.

After reconnection to the tractor, a $\mathrm{R} / \mathrm{S}$ release and a $\mathrm{Bill}$ of Lading for the empty cask were given to the truck driver along with an instruction package which included the routing, cask description, and énergency procedure. Finally, the cask and trailer were removed from the FRS. Before his departure from the site gate, the driver was required to give the $R / S$ release to the security of $f$ icer on dut y.

\section{4 Summary of Fuel Received}

Between 1973 and 1975, SNF assemblies containing 165 metric tonnes of spent fuel were shipped to NFS for storage. These are listed in Table 1. During 1978, six PWR type (WEPCO) SNF assemblies were removed from $F$ RS and shipped to Battelle Pacific Northwest Laboratory reducing the inventory to 750 SNF assemblies with 163 MTU. The location of the 750 fuel assemblies in the FRS pool by utility owners at the end of calendar year 1980 is shown in Figure 12 .

\subsection{Operating Time and Exposure}

The experience gained at NFS during the first reprocessing period between 1965 and 1971 resulted in considerable changes and modifications to the facility and to procedures before the FRS pool was operated as a storage facility after 1972. As an example, the average overall turn-around time for a shipping cask was reduced from 18 hours with 7 men during the earlier period to 3 hours with 2 men during the later period. The personnel radiological exposures were reduced from $0.5 \mathrm{E}-02 \mathrm{~Sv}$ ( $0.5 \mathrm{man}$ Rem) to $0.02 \mathrm{E}-02 \mathrm{~Sv}(0.02$ man Rern). 


\subsection{Upgrading the Facility}

The FRS and its equipment were not used for approximately eight years, from 1975 to 1983, during the time that the SNF assemblies were in storage. Before the removal campalgns started, the FRS equipment was refurbished and upgraded. Some new equipment was designed, procured and installed. All the equipment used in the campaigns was inspected, operationally checked, and tested. Cranes, fuel grapples, fuel lift racks, and all 1 ifting equipment and hardware were load tested. Procedures for operating these campaigns were updated, revised, reviewed, and approved. Safety Analysis Reports, Technical Specifications, Accountability Procedures, etc. were prepared for the new removal operations. New personnel were hired and trained to man the FRS. 
TABLE 1

SPENT NUCLEAR FUEL IN FRS

\begin{tabular}{|c|c|c|c|c|c|c|c|c|c|}
\hline Utilizy & Reactor/Type & $\begin{array}{l}\text { Number of } \\
\text { Sh1pments } \\
\end{array}$ & $\begin{array}{l}\text { Cask } \\
\text { Model } 1 \\
\end{array}$ & $\begin{array}{l}\text { Number of } \\
\text { Assemblies }\end{array}$ & MTU & $\begin{array}{c}\text { SNF } \\
\text { Assembly Size } \\
\end{array}$ & $\begin{array}{l}\text { Average Burn-up } \\
\text { MWD/MTU }\end{array}$ & $\begin{array}{l}\text { Reactor } \\
\text { Discharge }\end{array}$ & Date In \\
\hline $\begin{array}{l}\text { Commonweal th } \\
\text { Edison }\end{array}$ & $\begin{array}{l}\text { Dresden } 1 / \\
\text { BWR }\end{array}$ & 52 & NFS -4 & 206 & 20.429 & $\begin{array}{c}102 \mathrm{~mm} \times 102 \mathrm{~mm} \times 3404 \mathrm{~mm} \\
(4 " \times 4 " \times 134 ")\end{array}$ & $16 \mathrm{~K}$ & $9 / 69$ & $10 / 73-9 / 74$ \\
\hline $\begin{array}{l}\text { Rochester Gas } \\
\text { \& Electric }\end{array}$ & Ginna/PWR & 121 & NFS -4 & 121 & 46.156 & $\begin{array}{c}198 \mathrm{~mm} \times 198 \mathrm{~mm} \times 4064 \mathrm{~mm} \\
\left(7.8^{\prime \prime} \times 7.8^{\prime \prime} \times 160^{\prime \prime}\right.\end{array}$ & $10-21 \mathrm{~K}$ & $\begin{array}{l}3 / 71 \\
5 / 72\end{array}$ & $2 / 73-6 / 73$ \\
\hline $\begin{array}{l}\text { Cons'umers } \\
\text { Power }\end{array}$ & $\begin{array}{l}\text { Bíg Rock } \\
\text { Point/BWh }\end{array}$ & 10 & NFS-X2 & 85 & 11.130 & $\begin{array}{c}165 \mathrm{~mm} \times 165 \mathrm{~mm} \times 2134 \mathrm{~mm} \\
\left(6.5^{\prime \prime} \times 6.5^{\prime \prime} \times 84^{\prime \prime}\right)\end{array}$ & $11.3 \mathrm{~K}$ & $\begin{array}{l}6 / 68 \\
4 / 69 \\
2 / 71 \\
3 / 72 \\
4 / 73 \\
5 / 74\end{array}$ & $\begin{array}{r}2 / 73-9 / 73 \\
11 / 74\end{array}$ \\
\hline WEPCO & $\begin{array}{l}\text { Pt. Beach 1\&21 } \\
\text { PWR }\end{array}$ & 120 & NFS -4 & 120 & 45.298 & $\begin{array}{c}198 \mathrm{~mm} \times 198 \mathrm{~mm} \times 4064 \mathrm{~mm} \\
\left(7.8^{\prime \prime} \times 7.8^{\prime \prime} \times 160^{\prime \prime}\right)\end{array}$ & $32 \mathrm{~K}$ & $\begin{array}{l}9 / 72 \\
3 / 74\end{array}$ & $7 / 74-5 / 75$ \\
\hline GPU & Oyster Creek/ & 112 & NFS -4 & 224 & 42.756 & $\begin{array}{c}140 \mathrm{~mm} \times 140 \mathrm{~mm} \times 4394 \mathrm{~mm} \\
\left(5.5^{\prime \prime} \times 5.5^{\prime \prime} \times 173^{\prime \prime}\right.\end{array}$ & $13 \mathrm{~K}$ & $\begin{array}{l}9 / 71 \\
5 / 72 \\
4 / 73 \\
4 / 74\end{array}$ & $1 / 75-12 / 75$ \\
\hline
\end{tabular}




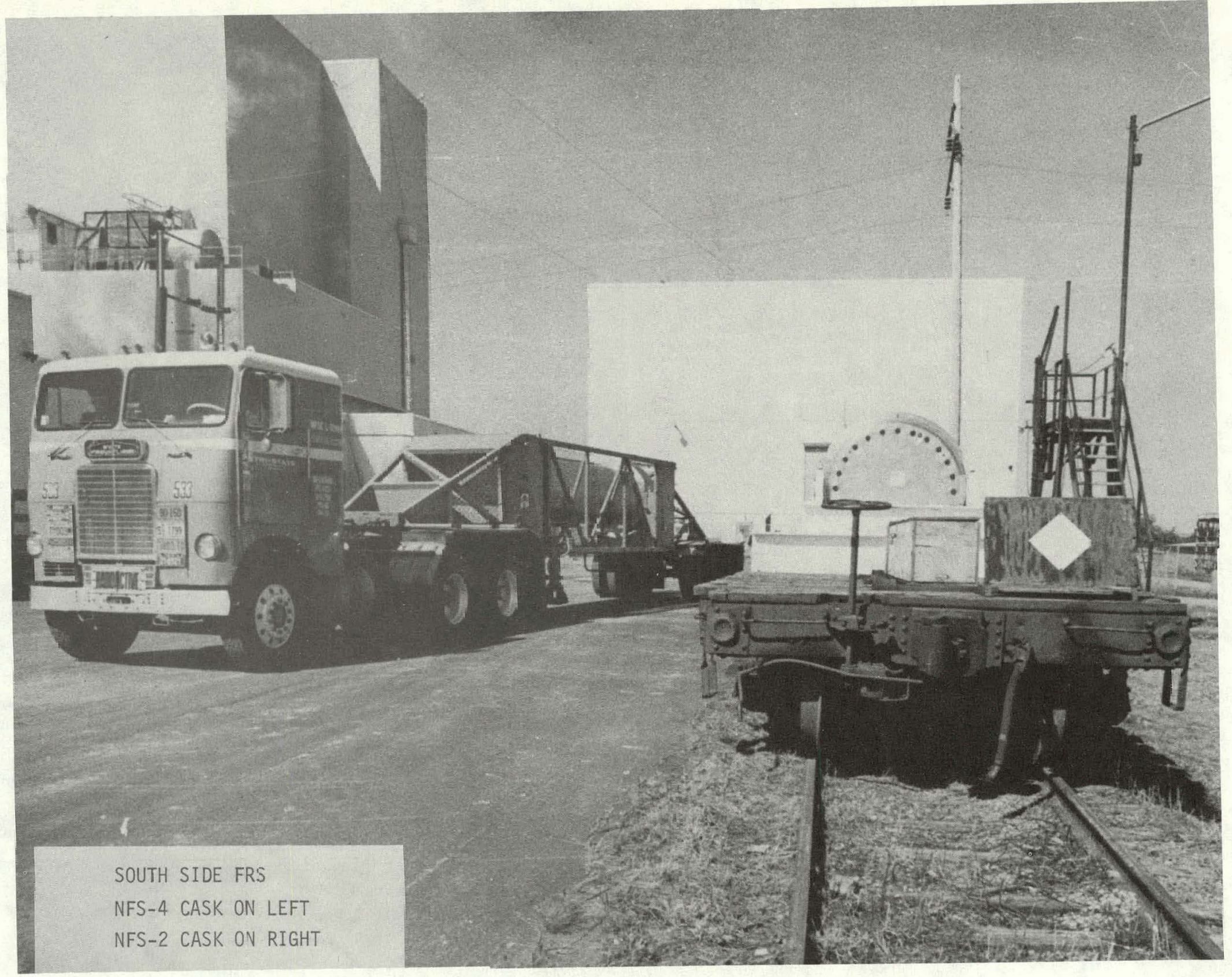

FIGURE 7

Truck and Rail Casks 


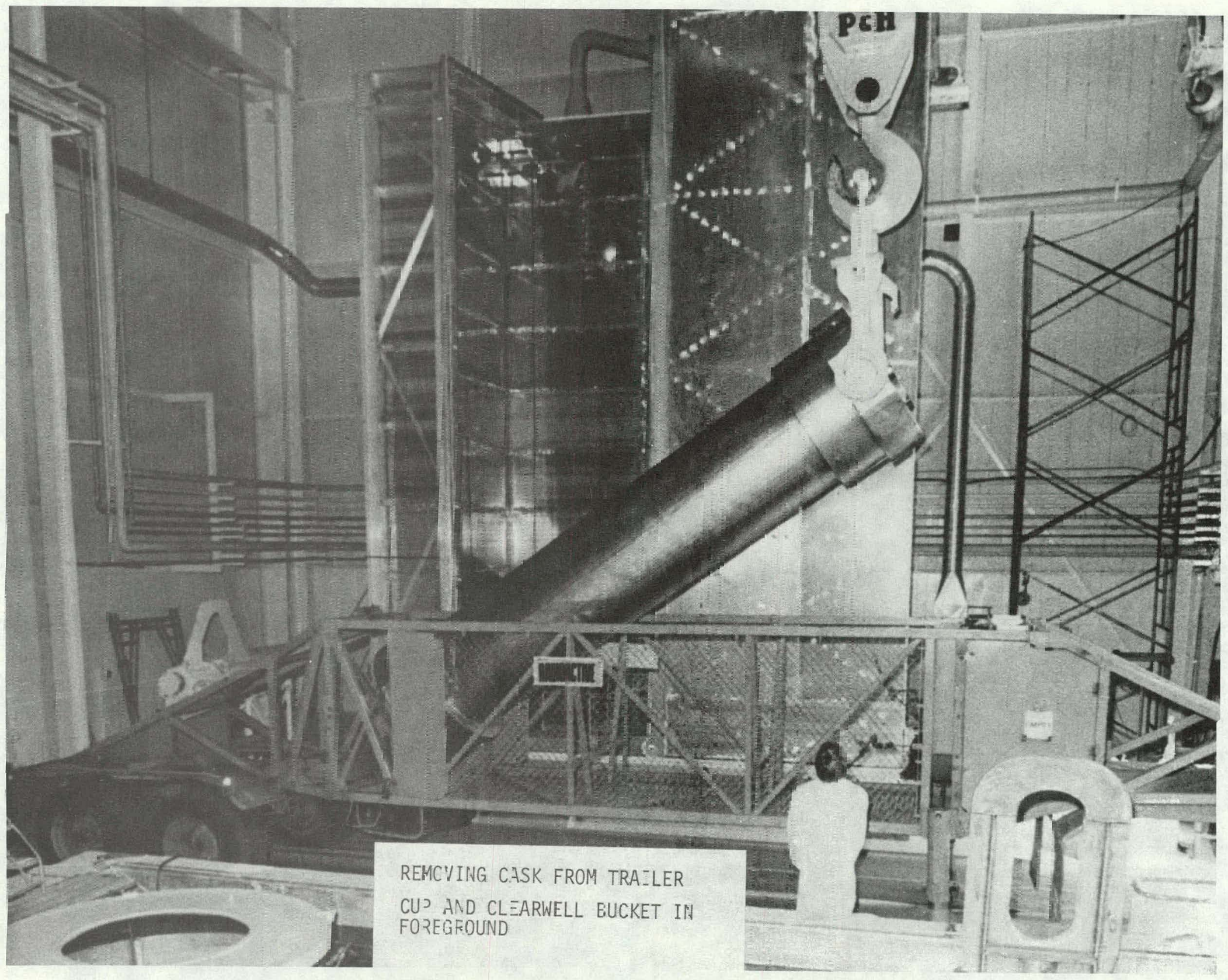

FIGURE 8

Removing Cask From Trailer 


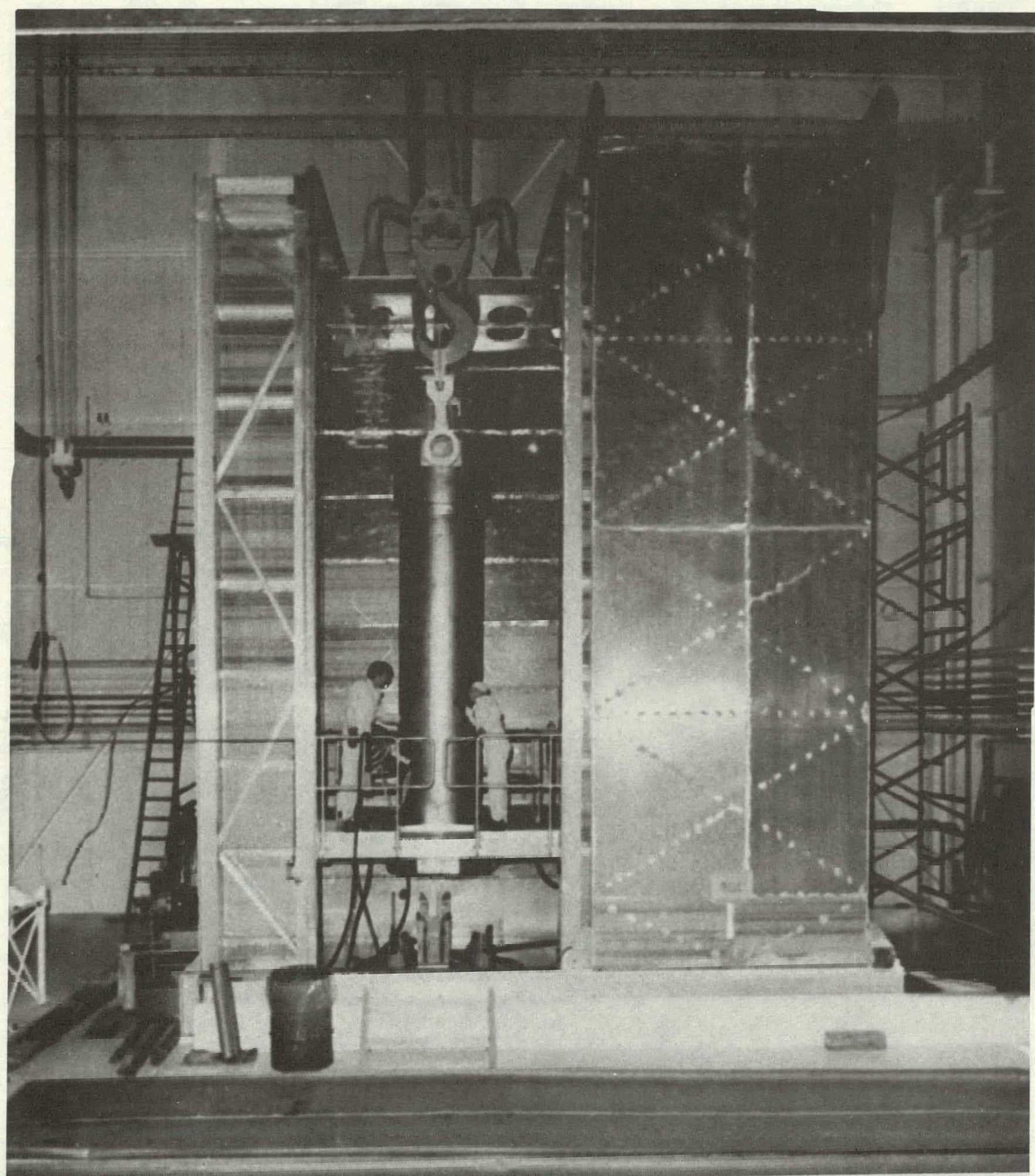

DECONTAMINATION SHROUD CHAMBER AT EAST END OF FRS

NFS CASK BEING LOWERED INTO POSITION

FIGURE 9 Installing Cask in Decontamination Stall 


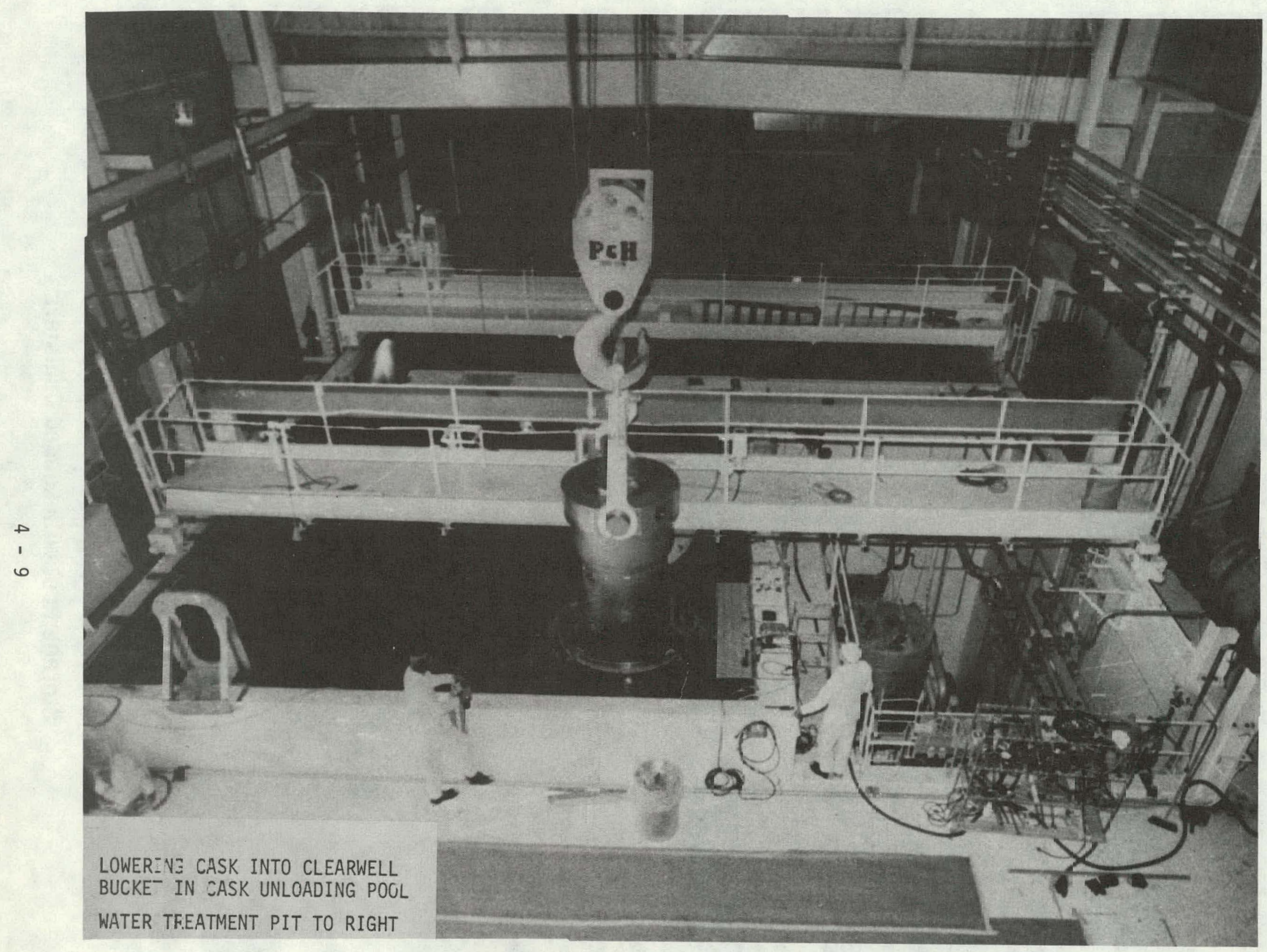

FIGURE 10

Lowering Cask in Clearwell Bucket 


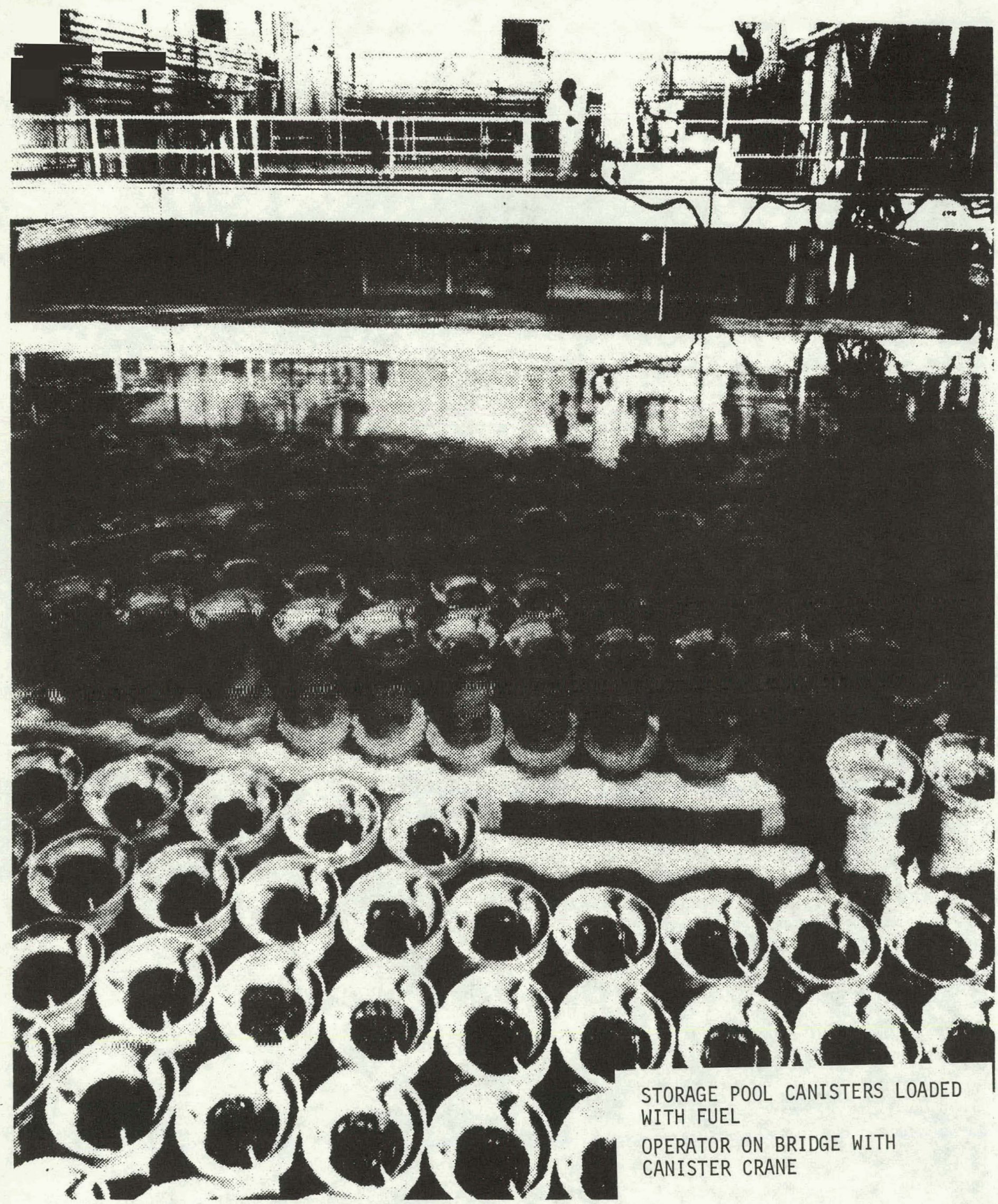

FIGURE 11

Storage Pool with Loaded Canisters 


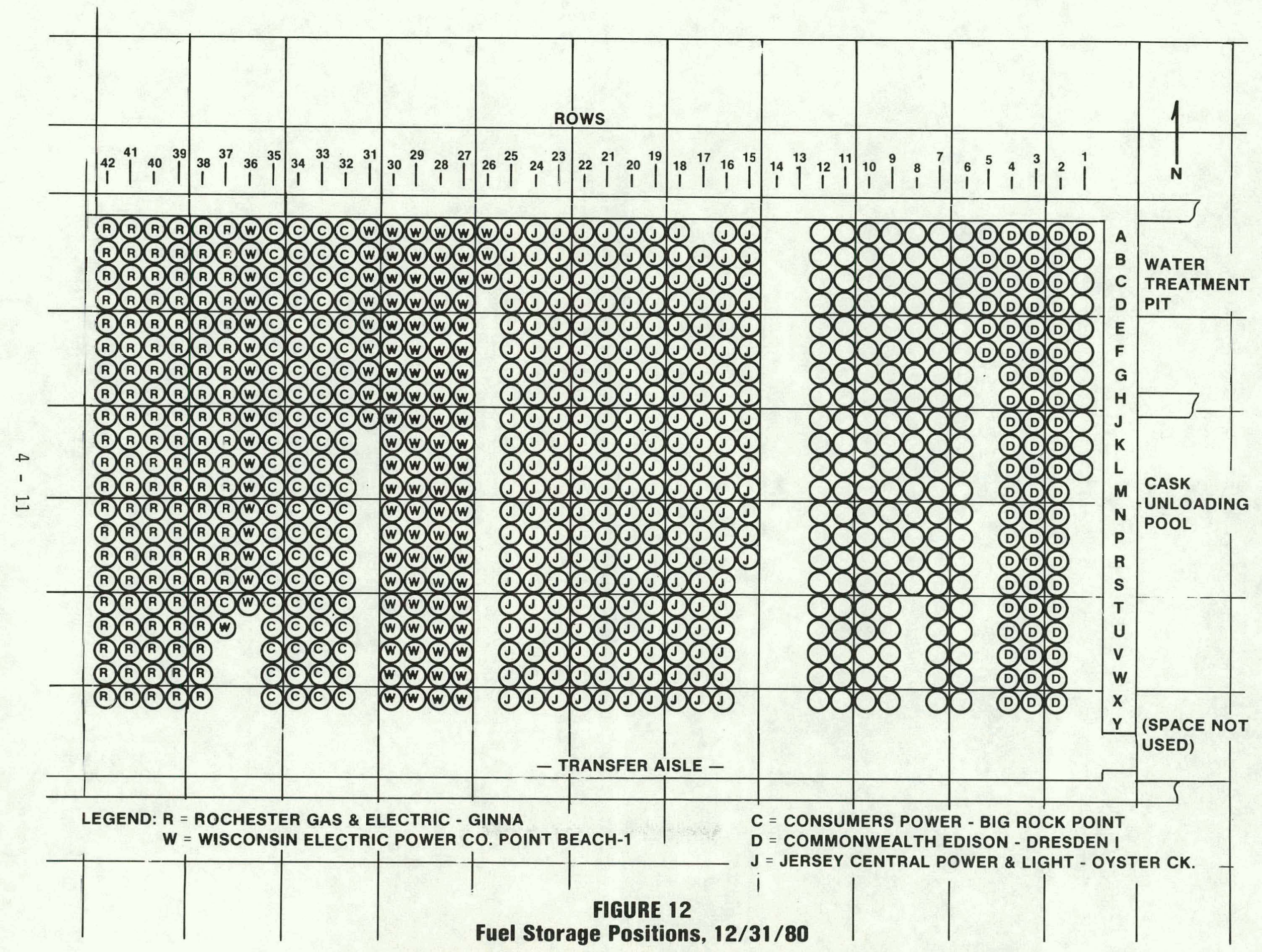




\subsection{SPENT NUCLEAR FUEL (SNF) INVENT ORY IN FRS}

The SNF assemblies removed, or to be removed, from the FRS pool is the same as the inventory given in Table 1 and Figure 12. However, there was a change in ownership of some of the SNF assemblies, and this change impacted the removal program to some extent.

\subsection{Change in Ownership}

For business reasons, NFS exchanged uranium product for SNF assemblies with two of the utilities listed in Table 1. Rochester Gas and Electric exchanged 40 PWR type SNF assemblies with NFS. Consumers Power exchanged 85 BWR type SNF assemblies with NFS. Thus, NFS became the owner of $40 \mathrm{PWR}$ and 85 BWR SNF assemblies, which contained a total of 26 MTU.

\subsection{NFS/DOE Contract}

In a 1986 contractual arrangement between NFS and DOE, NFS gave title to the above $26 \mathrm{MTU}$ of SNF assemblies to DOE. These $125 \mathrm{SNF}$ assemblies are to be used by DOE for shipping and storagc demonstration programs. Consequently, these SNF assemblies are to be shipped from West Valley to the Idaho National Engineering Labor atory (INEL).

\subsection{Description of SNF Assemblies in FRS}

Each of the SNF assemblies in FRS consists of dozens of 1 ong tubes bundled together in a square cross-section array. The SNF is, for the most part, uranium oxide pellets stacked inside the tubes. The overall dimensions of these assemblies depend on the design of the 
reactor core for which they were made, and are listed in Table 1, seventh column. Note that the Ginna PWR and the Point Beach PWR assemblies have the same overall dimensions. The SNF assemblies listed in Table 1 weigh between 317 to $635 \mathrm{~kg}$ (700 to 1400 pounds).

\subsection{Condition of SNF Assemblies}

After delivering their burn-up in the reactor core, these SNF assemblies were removed from the reactor during a refueling operation, and were stored in the reactor plant fuel storage pool for probably over a year. After shipment to NFS they have been stored in the FRS pool for 11 to 13 years. There were and are several SNF assemblies which are badly twisted and bowed as illustrated by the Figure 13 underwater photograph. In addition, there were many assemblies which had collapsed tubes and/or tubes with visible holes in them. 


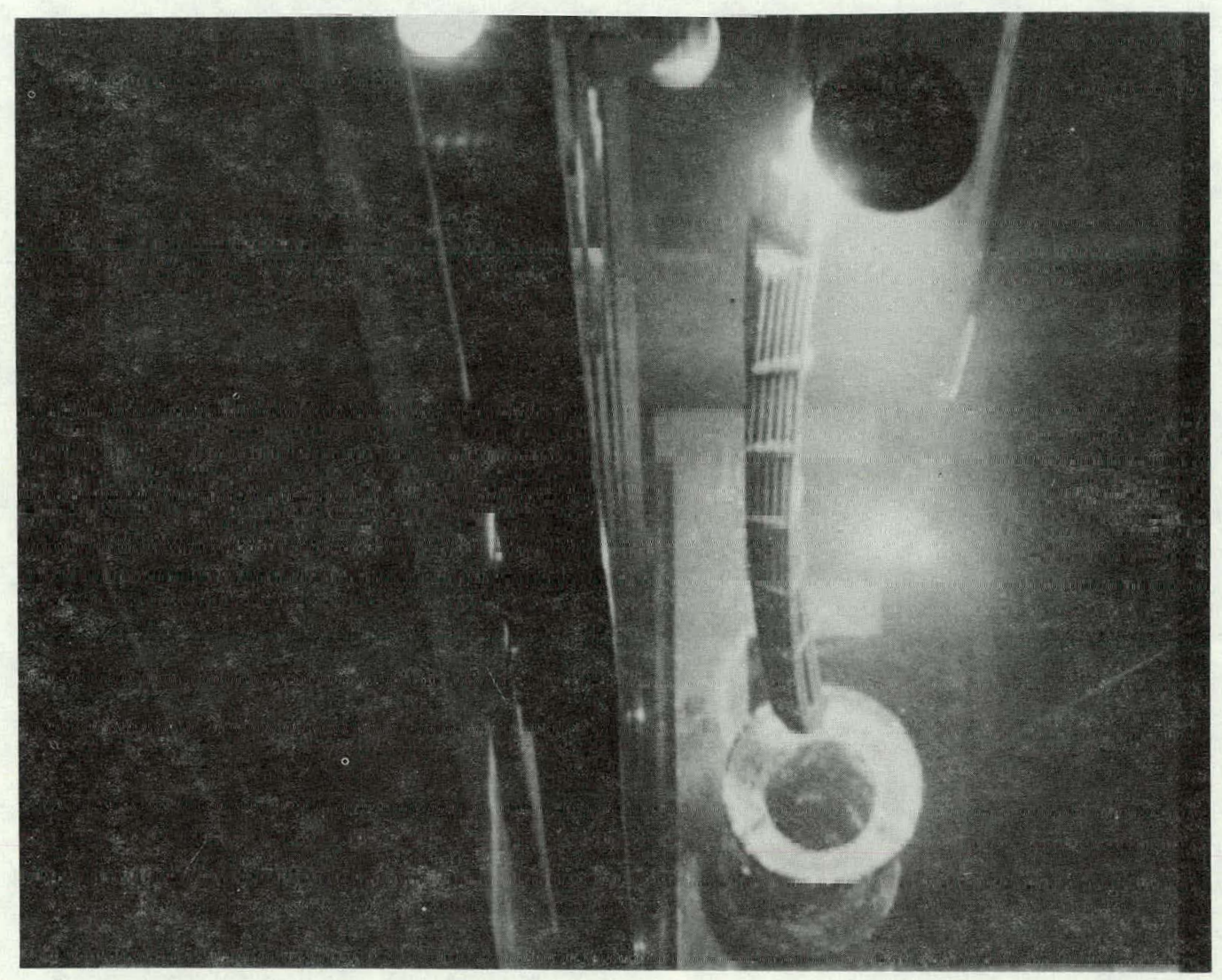

FIGURE 13

Twisted SNF Assembly 


\subsection{SNF SHIPPING CAMPAIGNS FROM WEST VALLEY}

Taking account of the transfers of ownership and title (see Sections 5.1 and 5.2), results in five SNF shipment campaigns from West Valley. These five campalgns are summarized in Table 2.

Some of these campalgns overlap each other chronologically to some extent. The Dresden campaign and the Point Beach campaign were conducted at virtually the same time. There was also considerable overlap in the Oyster Creek and Ginna campaigns. The Idaho National Engineering Laboratory (INEL) campaign is not expected to commence before mid-1987.

\section{1 Point Beach Shipping Campaign}

This campaign shipped 114 PWR type SNF assemblies back to the Point Beach NCS of the Wisconsin Electric Power Co. at Two Rivers, Wisconsin. There were $114 \mathrm{NLI} 1 / 2$ shipments, one for each assembly.

Shipping information and routing for this campaign is given in Table 4. Shipping events and legal activities are given in Reference 1, Section 2.1.2.

\subsection{Dresden Shipping Campaign}

This campaign shipped 206 BWR type SNF assemblies back to the Commonwealth Edison Company, Dresden Nuclear Generating Station (NGS) at Morris, Illinois. There were 31 shipments; 30 in the TN-9 cask and one in a NLI-1/2 cask. Shipping information and routing for this campaign is given in Table 3. Shipping events and legal activities for this campalgi are given in Reference 1 , Section 2.1.2. 
The spent nuclear fuel (SNF) shipments from West Valley, New York, to the Commonwealth Edison (CECO) Dresden nuclear generating station (NGS), Morris Illinois, and to the Wisconsin Electric Power Company (WEPCO) Point Beach NGS, Two Rivers, Wisconsin, had similar çharanteristics; for this reason. their case histories in Reference 1 are merged. Issues and concerns about selected routes, timing of the campaign, and safety 1 ssues were reflected in a series of civil cases, petitions, and letters of inquiries. There were candlelight vigils by citizen and environmental groups protesting the shipments in the proximity of the West Valley plant. Once the campaigns were underway, little conflict arose. However, during the campaigns, several administrative and judicial decisions resulting from earlier appeal actions were issued.

The Point Beach and Dresden shipping campaigns were both conducted from the fall 1983 to the fall 1984. West Valley to Point Beach shipments began on Uctober 4, 1983, three munths after a court order directing removal of SNF assemblies from the fuel storage pool at West Valley. (U.S. District Court, 1983), and ended a year later on October 6, 1984. The West Valiey to Dresden campaign began in December 1983 and was essent1ally conpleted on November 11, 1984. One bowed and twisted $S N F$ assembly, (see section 7.4.2) had to be shipped in a NC-1 cask. This last Dresden shipment left the WVDP on June 20, 1985.

The NRC-approved routes for transporting the SNF assemblies in these two campaigns are identical until a few miles beyond the intersection of $\mathrm{I}-80 \mathrm{~W}$ and the IIlinois-State line--at the $\bar{I}-55 \mathrm{~S}$ intersection. Shipments to Dresden NGS continued on I-55; to complete shipments to the WEPCO Point Beach facility, I-294 and I-94 $\mathrm{N}$ were used. 
These campaigns from West Valley moved 145 shipments, averaging 715 miles (one-way) per shipment, and 320 SNF assemblies (206 BWR types and 114 PWR types) containing approximately 63 metric tons, of uranium, to Point Beach and Dresden.

Both legal-weight trucks and overweight trucks were used. There was no specific institutional conflict arising over spent nuclear fuel transport in the overweight truck mode in the West valley to Dresden shipping campaign. However, transport vehicle braking-tests with unloaded casks imposed by New York Department of Transportation on all. West Valley spent nuclear fuel transport vehicles derived originally from requirements for overweight trucks.

\subsection{Oyster Creek Shipping Campaign}

The Oyster Creek campaign began about two months after the west Valley to Dresden and Point Beach campaigns were successfully completed.

There were 224 BWR type SNF assemblies shipped back to the Oyster Creek NGS of the General Public Utilities (GPU), Jersey Central Power and Light Co., at Forked River, N.J.

Shipping information and routing are given in Table 6. Reference 1 , Section 2.2.2 summarizes shipping events and legal activities.

The series of shipments of General Public Utilities/Jersey Central Power and Light (GPU/JCP\&L)-Owned spent huclear fuel from West Valley, New York, to Oyster Creek nuclear generating station located at Forked River, New Jersey, began on January 3, 1985, and ended on July 8,1985 . These shipments constituted the third shipping 
campaign completed without a transportation incident. Thirty-three shipments over approximately 6 months (excluding planning, preparation, and training) were required to transport the 224 SNF assemblies of approximately $43 \mathrm{MTU}$.

Trangnunlear, Ins., tho GPU/JCP\&L shippling agent, used two TN-9 casks - serial numbers 1 and 2, during this campalgn to fulfill the three shipments per biweekly schedule. These shipments removed all GPU/JCP\&L SNF assemblies from the FRS storage pool by the courtappointed date of May 31, 1985. The actual completion date was July 8, 1985, due to litigation over routing and other matters. (GPU/JCP\&L was not subject to penalties for failing to meet the court-ordered date.)

The loaded vehicle weight of approximately 115,000 lbs exceeded the maximum weight allowed without special permit by federal law for Interstate Highway System use. Exceptions to this weight limitation may be granted by special permits issued in accordance with applicable state laws. The use of an overweight truck precipitated a major problem between GPU/JCP\&L and the New Jersey Turnpike Authority (NJTA) immediately following completion of the first shipment of spent fuel to Oyster creek.

A major difference between the institutional issues that characterized the period preceding the Dresden and Point Beach campaigns and that before the start of Oyster Creek shipments was the absence of 10 CFR 2.206 petitions challenging the planned shipments. There were no special agreements with State agencies concerning escourt and other transport requirements. At the local government level (Lacey County, N.J.) a hastily enacted restrictive ordinance, The Lacey Ordinance (August 1983), to prohibit the 
importation of SNF assemblies into the Oyster Creek NGS, was denied by judicial means approximately 2 months (September 1984) prior to the original scheduled start of Oyster Creek shipments.

\subsection{Ginna Shipping Campaign}

During this campaign 81 PWR type SNF assemblies were shipped back to their owner Rochester Gas and Electric Co., Ginna NGS, at Ontario, N.Y., or to their designated recipient, Battelle Columbus Laboratonipg in West. iefferson. Ohio. There were 81 shipments.

Routing and other shipping information are given in Table 5 . Section 2.3.2 of Reference 1 provides shipping events and legal activities of this campaign.

Rochester Gas and Electric Company (RG\&E) was not a litigant in the court case that resulted in the West Valley spent fuel shipping campaigns. RG\&E had reached an agreement with NYSERDA on the removal of RG\&E-spent fuel prior to NYSERDA initiating legal action against Nuclear Fuel Services, Inc. (NFS) and the utilities. There were some interruptions during the campaign, which are described as follows:

\section{August 1985}

Shipments are temporarily suspended for about 1 week due to abnormally high traffic levels during the Erie County fair in Hamburg, New York.

De cember 1985

A second postponement occurred (from November 27, 1985 to January 7,1986 ) when RG\&E, in conjunction with DOE, sponsored a demonstration of spent fuel rod çonsolidation techniques at west Valley using RG\&E fuel. 
Januar y 1986

Shipments of unconsolidated fuel rods resume along wi.th some shipment of fuel rods which had been consolidated in the rod consolidation demonstration performed for RG\&E and DOE by the Nuclear Assurance Corporation, RG\&E's shipping agent.

\subsection{INEL Shipping Campaigns}

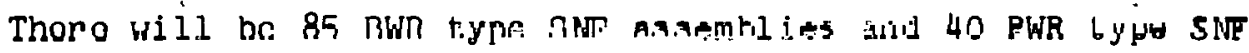
assemblies in two demonstration casks shipped by rail for this campaign to INEL near Idaho Falls, Idaho.

Known routing and other shipping information are given in Table 7 . Note that much of this information has not yet been determined. Section 2.4 of Reference 1 gives other available information about this future campaign.

These SNF assemblies were originally earmarked for shipment to Dak Ridge National Laboratory. The destination was subsequently changed to INEL, and the shipment effort has evolved into a cooperative agreement between DOE and NFS to demonstrate the feasibility of transport and long-term storage utilizing dual purpose casks designed expressly for these purposes. Because DOE has taken title to the fuel prior to shipment, the shipments, including loading and preparation for transfer to a carrier, will be exempt from NRC authorit.y.

One dual-purpose, $90.7 \mathrm{Mg}$ (100-ton) cask has been scheduled to he loaded with the $40 \mathrm{PWR}$ type SNF assemblies and the other dual purpose $90.7 \mathrm{Mg}$ (100-ton) cask has been scheduled to be loaded with the 85 BWR type SNF assemblies. These shipments comprise the äpproximately $26 \mathrm{MTU}$ of SNF assemblies under DOE license. However, when concerns and questions were raised in the summer of 1985 over the equivalence of DOE's and NRC's cask certification process, DOE of $f$ icials decided to defer to NRC for certification of the casks. 
TABLE 2

MEST VALLEY SPENT FUEL SHIPHENTS

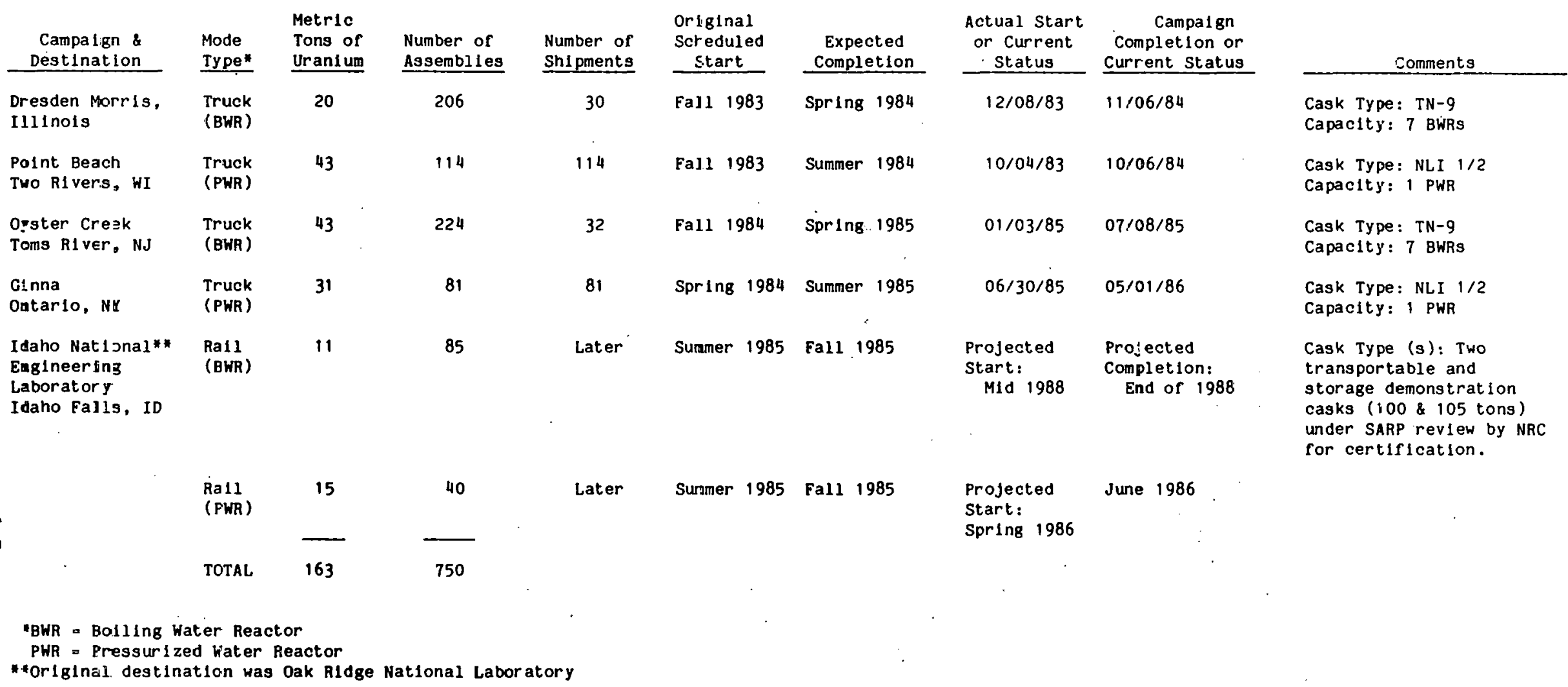


TABLE 3

UEST VALLEY TO DRESDEN SHIPPING CARPAIGI--SUPPLETEMTARY DETAIL

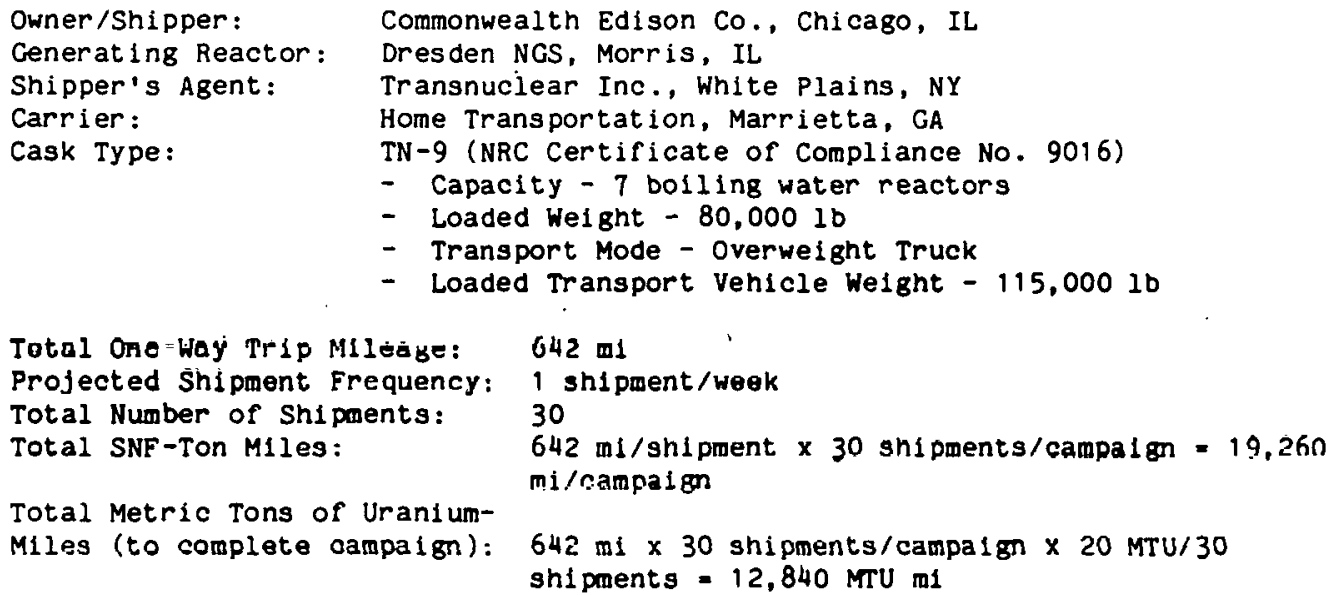

New York

1. West Valley NFS Facility via

Schwartz Road to US 219

2. US $219 \mathrm{~N}$ to $N Y 39$

3. NY $39 W$ to U3 20

4. US 20 to NY 60

5. NY $60 \mathrm{~N}$ to I-90 (NY Thruway)

6. I-90 S to Pennoylvania State Line

Subtotal

4

8

32

0.5

28.0

74.9

Pennsyl vania

7. I-90 W to I-79

8. I-79 S to $I-80$

y. I-80 W to ohio state Line

Subtotal

Uก 18

10. I-80 $W$ to Indiana State Line 237

Subtotal $\quad 237$

Indiana

11. I-80 $\mathrm{W}$ to Ill1nols State LIne 151

$\begin{array}{ll}\text { Subtotal } & 151\end{array}$

Il11nois

12. $I-80 W$ to $I-55 S$

13. I-55 via Lorenzo Road to Dresden 50

Subtotal $\quad \underline{80}$

GRAND TOTAL $\quad 642$ 
TABLE 4

\section{MEST VALLEY TO POINT BEACH SHIPPING CAMPAIGN--SUPPLEMENTARY DETAIL}

Owner/Shipper:

Generating Reactor:

Shipper's Agent:

Carrier:

Cask Type:
Wisconsin Electric Power Company, Milwaukee, WI

Point Beach NGS, Two Rivers, WI

Nuclear Assurance Cor poration, Norcross, GA

Tri-State Motor Transit Company, Jopl in, MO

NLI 1/2 (NRC Certificate of Compliance No. 9010)

- Capacity - 1 pressurized water reactor

(or 2 bolling water reactors)

- Loaded Weight - 44,000 10

- Transport Mode - Legal Weight Truck (LWT)

- Loaded Transport Vehicle Weight - 72,000 lb

Total One-Way Trip Mileage: $784 \mathrm{mi}$

Projected Shipment Frequency: 3 shipments/week

Total Number of Shipments: $\quad 114$

Total SNF-Ton Miles: $\quad 784 \mathrm{mi} /$ shipment $\times 114$ shipments/campaign $=89,376$ $\mathrm{mi} / \mathrm{campai} \mathrm{gn}$

Total Metric Tons of UraniumMiles (to complete campaign):

$784 \mathrm{mi} \times 114$ shipments/campaign $\times 43 \mathrm{MTU} / 114$ shipments $=33,712$ MTU miles

Road Transport Route

Distance (mi)

New York

11. West Valley to Dresden Route to Illinois State line (Table 3)

Subtotal

562

Illinois

12. I-80 W to I-294 4

13. I-294 N to I-94 53

14. I-94 $\mathrm{N}$ to Wisconsin state Line 25

Subtotal $\quad 82$

Wisconsin

15. I-94 N to I -43

16. I $-43 \mathrm{~N}$ to WI -147

17. WI-147 E to WI -163

18. WI-163 to Nuclear Road 2

19. Nuclear Road to Point Beach Facility 5

Sibtotal $\underline{140}$

GRAND TOTAL $\quad 784$ 
TABLE 5

NEST VALLEY TO GINNA SHIPPING CAMPAIGN--SUPPLEMENTARY DETAIL

Owner/Shipper:

Generating Reactor:

Shipper's Agent:

Carrier:

Cask Type:
Rochester Gas and Electric Company, Rochester, NY Ginna NGS, Ontario, NY Nuclear Assurance Corporation, Norcross, GA Tri-State Motor Transit Company, Joplin, MO NLI - 1/2 (NRC Certificate of compliance \#9010)

- Capacity - pressurized water reactor (or 2 boiling water reactors)

- Loaded Weight - 44,000 1b

- Transport Mode - Legal-Weight Truck

- Loaded Transport Vehicle Weight - $158.5 \mathrm{mi}$

Total One-Way Trip Mileage: $\quad 158.5 \mathrm{mi}$

Projected Shipment Frequency: 1 to 7 shipments/week

Total Number of Shipments: 81

Total SNF-Ton Miles: $\quad 12,838$

Total Metric Tons of Uranium-

Miles (to complete campaign): 4,913

Road Transport Route

Distance (mi)

New York.

1. West Valley NFS Facility via

Schwartz Road to US 219

2. US $219 \mathrm{~N}$ to I-90 (Thruway)

3. I-90 E to NY 21 (Exit 43, NY Thruway)

4. NY 21 to Hackett Road

Hackett Road to Yellow Mill Road

Yellow Mill Road to NY 31

NY 31 W to NY $31 \mathrm{~F}$

NY 31 F to NY 350

4

32

85

NY 350 to Ginna NGS

$\underline{37.5}$

Total (a complete intra-state route)

158.5 


\section{WEST VALLEY TO OYSTER CREEK SHIPP ING CAMPAIGN--SUPPLEMENTARY DETAIL}

Owner/Shipper:

Generating Reactor:

Shipper's Agent:

Carrier:

Cask Type:
GPU/Jersey Central Power \& Light Company, Morristown, NJ Oyster Creek, NGS, Forked River, NJ

Transnuclear Inc., White Plains, NY

Tri-State Motor Transit Company, Jopl in, MO

TN-9 (NRC Certificate of Compliance No. 9016)

- Capacity - 7 boiling water reactors

- Loaded Weight - 80,000 lb

- Transport Mode - Overweight Truck

- Loaded Transport Vehicle Weight - 115,000 Ib

(2 TN-9s - Serial No. 1 \& 2 used in this campaign)

Total One-Way Trip Mileage: $531 \mathrm{mi}$ (per NRC approved road route, 9/84)

Projected Shipment Frequency: 3 shipments/biweekly

Total Number of Shipments: 32

Total Metric Tons of Uranium-

Miles (to complete campaign): Not Available

Road Transport Ro:dte

Distance (mi)

New York

1. West Valley NFS facility via

Schwartz Road to US 219

2. US $219 \mathrm{~N}$ to I-90 (NY Thruway)

3. I-90 north/east to I-481

4. I- I 181 south to $I-81$

5. I-81 south to Pennsylvania Line

Pennsylvania

6. $I-81$ S to $I-380$

7. I-380. E to $I-80$

8. I-80 E to $\mathrm{NJ}$ Line

Subtotal

Onio

9. I-80 E to $\mathrm{I}-287$

10. I-287 S to I-95 (NJ Turnpike)

11. I-95 $S$ to $I-195$

12. I-195 W to $\mathrm{NJ} 537$

28

13. NJ 537 E to $\mathrm{NJ} 571$

14

14. NJ 571 S to NJ Garden State Parkway (NJGSP)

15. NJGSP $S$ to Lacey Road

16. Lacey Road $E$ to US -9

17. US 9 to Oyster Creek NGS

Subtotal 


\subsection{SNE SHIPPING OPERATIONS}

The shipping out of the SNF assemblies from the WVDP was similar to the shipping in and unloading operations sumnarized in Section 4.0, and consisted of: a) receipt of the empty cask on site, b) removing the cask from the tank in FRS, c) prepping the cask in the decontamination stall for the CUP operations, d) installing the cask in the CUP while isolating it from the contaminated pool water, e) transferring the SNF assembly(ies) in their canisters firom the fuel storage pool into the CUP, f) placing the SNF assembly (ies) into the cask, g) closuring the cask and removing it from the CUP $h$ ) transferring the cask to the decontamination stall, i) prepping the loaded cask for shipping, $j$ ) installing the cask on its truck, and $k$ ) completing the decontamination for shipping.

\subsection{Safety Considerations}

The SNF Removal Program at West Valley was planned and performed in conformance with program safety criteria. This criteria consisted of six major topics as follows:

7.1.1 Ensure the safety of all operating personnel

7.1.2 Ensure the safety of the public at all times

7.1.3 Ensure the protection of the environment at all times

7.1.4 Reduce personnel and public exposure to radiation to "as low as reasonably achievable" (ALARA). This included reducing the handling and loading times of the SNF assemblies, and making all involved operations as efficient and safe as achievable.

7.1.5 Comply with Federal, State, and Local ordinances

7.1.6 Operate efficiently arid mlnlmlze costs 


\subsection{Types of Shipping Casks}

There were two types of casks used in the shipping campaigns from West Valley: the $\mathrm{NLI} 1 / 2$, the $\mathrm{TN}-9$. The $90.7 \mathrm{Mg}$ (100-ton) dual purpose (transportation and storage) casks are to be used for the INEL shipping campaign.

\section{2 .1 NLI $1 / 2$ Casks}

The 1 NLI $1 / 2$ cask made by National Lead Industries (NLI), was used for the Point Beach and Ginna campaigns. It has the capacity to hold one PWR type fuel assembly or two BWR assemblies as indicated by the "1/2" desi gnation. Each cask has a loaded weight of $19,958 \mathrm{~kg}(44,000 \mathrm{lbs})$. The NRC Certificate of Compliance is No. 9010 . The transport mode is by legal weight truck, and the loaded transport vehicle weight is $32,658 \mathrm{~kg}(72,000 \mathrm{lbs})$. Figure 14 shows one of these casks being lowered in the FRS and secured to its trailer and truck ready to roll.

\subsubsection{IN-9 Cask}

This cask, made by Transnuclear, Inc. (TN) and designated model 9, was used for the Dresden and Oyster Creek campaigns. It has a capacity to hold seven BWR type fuel assemblies, and has a loaded weight of $36,287 \mathrm{~kg}(80,000 \mathrm{lbs})$. The NRC Certificate of Compliance is No. 9016. The transport mode is by overweight truck, and the loaded transport vehicle weight is $52,163 \mathrm{~kg}(115,000 \mathrm{lbs})$. Figure 15 shows this cask being $l$ ifted in the FRS, and as installed on its trailer and truck. 


\subsection{Mg (100-Ton) Dual Storage Cask}

Two casks will be used for the INEL campaign. They were made by Transnuclear, Inc. for a one-time usage. The TN-REG cask will be used to contain the 40 PWR type SNF assemblies, and the TN-BRP cask will be for the 85 BWR type SNF assemblies. The Safety Analysis Reports for these casks are now under review for NRC cask certification.

These casks are designed for rail transportation. They will also be used for dry storage, as a demonstration project, the transported SNF assemblies.

\subsection{Cask Operations}

After the truck with the empty shipping cask arrives at the west Valley facility, the truck and cask are thoroughly inspected and all receipt documents completed and signed. The truck is then driven into the FRS Cask Unloading Area, and after surveying, the cask cover and overpack are removed.

\subsubsection{Removal from Truck}

The empty cask is rigged for lifting, and lifted to the vertical on the truck cradle using the $90.7 \mathrm{Mg}$ (100-ton) FRS cask crane. The cask is then lifted of $f$ of the trailer and transferred to the FRS decontamination stall within the stall spray ring and platform.

\subsubsection{Prepping the Empty Cask}

Inside the stall, the empty cask internal pressure and temperature are checked. The cask is then externally cleaned 
with pressurized water sprays and $r$ insed with demineralized water. It is surveyed to assure that any surface contamination is below allowable levels.

\subsubsection{Clearwell Bucket and Vinyl Cover}

After deconning and cleaning all surfaces, a NLI $1 / 2$ cask is moved, using the $90.7 \mathrm{Mg}$ (100-ton) crane, to the clearwell bucket in the CUP, and the cask lowered into the clearwell bucket. The cask inner closure head is removed. The clearwell bucket is then moved to the lower $(13.4 \mathrm{~m}$ ( $(44$ foot)) depth) floor elevation in the CUP.

The TN-9 cask does not $f$ it into the clearwell bucket. To keep its outer surfaces isolated from the contaminated CUP water, a vinyl cover is placed over and sealed to the cask with special water reslstant lape in the decontamination stall. When the covered cask is in the CUP, clean deminerallzed water fills the space between the cask and the vinyl cover. Thls water hä a emall pressure head from an elevated tank to assure outward leakage into the CUP.

\subsubsection{SNF Assembly Handling}

The selected SNF assembly and its canister are removed from the storage rack position in lhe storage pool (by meano of the fuel canister crane on the fuel sturage puil bridge), and placed on the lift rack in the CUP. The lift rack is moved to its lower position, and the SNF assembly is transferred froun its storage canister into the transport oask located in the CUP (using the fuel hoist on the CUP service bridge). 


\subsubsection{Loaded Cask Handling}

After the cask inner closure head is installed, the clearwell bucket with the loaded NLI $1 / 2$ cask inside is moved by the 90.7 Mg (100-ton) crane to the cask handling position in the CUP. The loaded cask is then removed from the clearwell bucket, out of the CUP, and placed in the decontamination stall for shipping preparations.

As the TN-9 cask with its vinyl cover is lifted out of the CUP, it is manually sprayed with water to rinse the vinyl cover of any contaminated pool water, as shown in Figure 16. The vinyl cover is removed from the $\mathrm{TN}-9$ cask in the decontamination stall, $r i n s e d$ of $f$ and hung in storage for the next use.

The cask cavity is pressurized with alr to $68.9 \mathrm{k}$ Pa to $103.4 \mathrm{k}$ $\mathrm{Pa}(10-15$ psig) via the vent forcing the remaining water trapped in the cask cavity to drain through the drain valve. In addition to draining, the shipping procedure includes the following:

- Torque the lid bolts to at least $135.5 \mathrm{~N}^{\circ} \mathrm{m}(100 \mathrm{ft} .1 \mathrm{~b})$.

- Attach the pressure check assembly to the gasket check Iine.

- Open the gasket check valve and pressurize the double $0-r i n g$ seal with utility air line pressure to $690 \mathrm{k} \mathrm{Pa}$ (100 psig). Cluse the alr supply valve on the pressure check assembly.

- Check for a drop in pressure. If the pressure should drop within nne minute, replaoe the o-ring and retest. 
- Vent the pressure from between the 0-rings.

- Close the gasket check valve and remove the pressure check assembly.

- Attach the pressure check assembly to the cavity vent line.

- Open the vent val.ve and pressurize the cask cavity with $552 \mathrm{k} P a(8 \mathrm{U}$ psig) alr.

- Close the vent valve and remove the pressure check as sembly.

- Check the drain and vent ball valves for air leaks by depressing the valves in the quick disconnects.

- Attach a vent line to the vent valve. and.purge the air from the cask cavity to the ventilation system.

- Remove the vent line, close-the vent valve, and replace and lockwire all (5) port covers.

\subsubsection{Placing the Cask on the Truck}

After a washdown in the decontamination stall, a $R / S$ survey for contamination of external services is performed and any indicated decontamination is completed at this point. placement of the cask on the trailer is then started, and includes the following steps:

- After arrival at the plant, the truck and empty trailer are inspected and surveyed for contamination, and the required forms received. 
- After these activities have been completed, the trailer is moved into the FRS for loading.

o Using the $90.7 \mathrm{Mg}$ (100-ton) crane, attach the cask lifting yoke to the cask upper trunnions.

- Load the cask onto the trailer by carefully placing the lower trunnions into the tie downs at the back end of the trailer.

- Lower the cask to the horizontal position while keeping the $90.7 \mathrm{Mg}$ (100-ton) crane cables vertical.

- Remove the yoke from the cask and store.

- Tie down the upper and lower trunnions.

- Attach the Iid impact limiter to the cask and torque the four $25.4 \mathrm{~mm}$ ( 1 -inch) bolts to $135.5 \mathrm{~N}^{\circ} \mathrm{m}(100 \mathrm{ft}:$ ) lb.

\subsubsection{Final Preparations}

A final Radiation and Safety Department survey is conducted. If levels indicated by that survey are within Federal and WVDP shipping limits, the trailer personnel barriers are installed and latched, the "radioactive" labels are attached and placards are installed.

The truck tractor and trailer are inspected by an independent mechanic who is a certified New York State vehicle inspector. In addition, the New York State Department of Transportation (DOT) has the option of performing a final vehicle inspection. 
The truck driver's shipping papers are completed. These consist of the Bill of Lading, the Radioactive Shipment Record, the Driver's Instruction for Exclusive Use and the Routing and Emergency Procedures. The Operations Shift Supervisors and a Quality Assurance Representative independently review the completed procedural check-off list and shipping documents. On the day of shipment, DOE certified that the cas $k$ was loaded in accordance with the procedures. The utility representative reviewed the shipping papers and signed them. The driver is given his copy and the recipient's copy of these papers. The DOE representative provided a copy of the shipping papers for the NRC representative, who reviewed the papers when he attended these shipping meetings. Attendance was optional for the NRC, and their representative was not present for all meetings.

\subsubsection{Operations for the Other Casks}

The operations given above in 7.3.1 to 7.3 .7 are generally for the NLI $1 / 2$ casks where one PWR type SNF assembly at a lime is loaded. The operations also apply for the $\mathrm{TN}-9$ cask loading scheme where seven BWR type SNF assemblies are plaged in this cask. In that case, the operations described in 7.3.4 would be repeated seven times. The loaded TN-9 cask was vacuum dried.

For the yU.7 Mg (ruU-ton) Dua $\perp$ Pur pose Casks, the cask handling operations would be similar to those given in 7.3 .1 to 7.3 .7 with the exceptions that the SNF assembly handling (see 7.3 .4 ) operations would be repeated 40 times for the TNREG Cask and 85 times for the TN-BRP cask.

\subsection{Unexpected Events}

Most of the SNF assembly removal operations went according to the 
procedures and were uneventful. Naturally there were a few unè xpected events.

\section{4:1 The Red Oxide Problem}

During the Oyster Creek Campaign a red oxide flaked of the BWR SNF assemblies as a result of the vacuum drying process. This clouded the water in the cask and CUP so that visibility for loading the following SNF assemblies in the same cask was greatly reduced. This made their cask loading very difficult and time-consuming. This red oxide tinted the CUP, and resulted in high radiation levels in drain lines when the cask was being drained in the decontamination stall. It.was determined that this material was iron oxide from the GPU SNF assemblies which were BWR type. The iron oxide came from condensate in the BWR plant cycle and deposited on the SNF assemblies. Recovery from this unplanned event resulted in considerable delay and additional expended effort.

\subsubsection{Bowed and Twi sted SNF Assemblies}

Approximately a dozen of the SNF assemblies out of the 625 that were handled in the four completed campaigns were noticeably twisted and/or bowed. One of these is shown in Figure 13. Thcoc grosely distortiod SNF assemblies were removed from their canisters and loaded in casks without serious consequences. However, there were additional time delays due to the extra care required in handling operations. The Figure $13 \mathrm{SNF}$ assembly was shipped by itself in a NLI $1 / 2$ cask to the Dresden NGS as reported in section 6.2 .

7.4.3 Damaged Fuel Rods During the completed campaigns there were several SNF 
assemblies with damaged fuel rods. These were discovered by underwater video observation during inspection of the SNF assemblies as they were withdrawn from their canisters in the CUP. Damaged rod assemblies were inserted into special failed fuel canisters. These canisters were then placed in the shlpping casks following standard procedures.

\subsubsection{Distorted Grids}

Some of the SNF assemblies that were handled during the four campaigns, had a grid (or grids), which space and hold the fuel rods buridled in postition, were distorted and misshapen. These too were revealed during underwater visual Inspection as the assemblies were being withdrawn from their canisters. Speclal falled fuel canisters (see section 7.4.3) were also used to handle these assemblies.

\subsubsection{Regulatory Problems}

Again, these problems are associated with transportation, and involved the New Yurk state iưl interpretation of regulations. Problems were experienced in the areas of 1) DOT III Labels, 2) Truck escort requirements, and 3) truok nverupight rostriotiono.

\subsubsection{Inspection Problems}

During the 12 hour pre-ship survey, certain areas of the shipping cask tended to leach out. (The surface contamination increased with time.) This caused considerable delay and additional cleaning.

WVNS has a policy that casks have to be surveyed within 12 hours before shipment. This policy was instituted due to the fact that cask surfaces which have been exposed to contamination (i.e. pool water) have a tendency at times to leach contamination from the pores of the cask surface. The 
purpose of the survey was to ensure that cask surfaces were well within the allowable limits as prescribed by 49 CFR 173.400 and $10 \mathrm{CFR} \mathrm{71.} \mathrm{When} \mathrm{cask} \mathrm{surfaces} \mathrm{were} \mathrm{found} \mathrm{not} \mathrm{to}$ meet this criteria, the cask would be decontaminated and resurveyed.

\subsection{Fuel Rod Consolidation Program}

During calendar year 1985 and early 1986, a fuel rod consolidation program was conducted at WVDP FRS using six SNF assemblies from the Ginna campaign inventory. This program was conducted to run in parallel with some of the WVDP SNF removal program operations.

A total of 1074 fuel rods were pulled from the six SNF assemblies without any significant problems. A compaction ratio of 1.8 to 1 was attained. This program is reported in more detail by Reference 2.

\subsection{FRS Pool Dismantlement}

During the SNF removal program campaigns, activities were performed for dismantling the FRS pool canisters and their holding racks. This is to provide space in the pool for underwater size reduction equipment and operations.

\subsubsection{Operation}

A special canister cutting rig (CCR) was designed and built to cut the ends and support ring sections out of the canisters. This CCR was installed in the northeast corner of the FRS storage pool. The CCR was essentially an aluminum structural frame which supported a rotating $j i g$ that held the canisters. The cutters were also mounted on this structure. The structure itself was attached to the east wall of the storage pool under four feet of water. 
Development studies were conducted in place to render the CCR operational. High pressure water jets with cutting abrasives (garnet powders), were first tried for the actual cutting medium. Problems with the clouding of the pool water and clogging of the pool water filters resulted in the adoption of saw type cutters for these operations.

\subsubsection{Results}

As the SNF assemblies were removed from the canisters in which they were stored in the FRS pool and shipped back to their utility uwlets, lite emply canisters were stored in the pool until they could be size-reduced in the CCR. There the empty canisters were cut in four places ( 5 pieces) to remove the ends and support ring.

After some decontamination in the storage pool, the ends and support ring sections of the canisters were placed in 208 Litre ( 55 gallon) drums for disposal. The cylindrical lengths were taken out of the pool to a speclal canister cylinder hydraulic crushing machine (CCCM) where they were essentially flattened. They were then placed in standard B-25 steel boxes, which are approximately $1219 \mathrm{~mm} \times 1219 \mathrm{~mm} x$ $1829 \mathrm{~mm}$ long ( $4 \mathrm{ft} . x 4 \mathrm{ft} . x 6 \mathrm{ft}$. ), for disposal.

These canister size reduction operations were being performed as the schedule permitted during and between the SNF four removal campaigns. About three months after the fourth SNF removal campaign was completed, all of the pool storage canisters that were scheduled for size reduction were cut and prepared for waste disposal. 
The FRS storage pool racks that supported the canisters will be dismantled by divers, and removed from the pool. These rack sections will be placed in special steel boxes $4877 \mathrm{~mm}$ (16 ft) long, $3658 \mathrm{~mm}$ (12 ft) wide, and $762 \mathrm{~mm}(2-1 / 2 \mathrm{ft}$ ) high, for disposal.

Canisters with the SNF assemblies for the last INEL campaign and their support racks are stored in the west end of the FRS pool. Here they will be relatively isolated from the east end of the pool where preliminary decontamination and underwater size reduction operations can be conducted. 

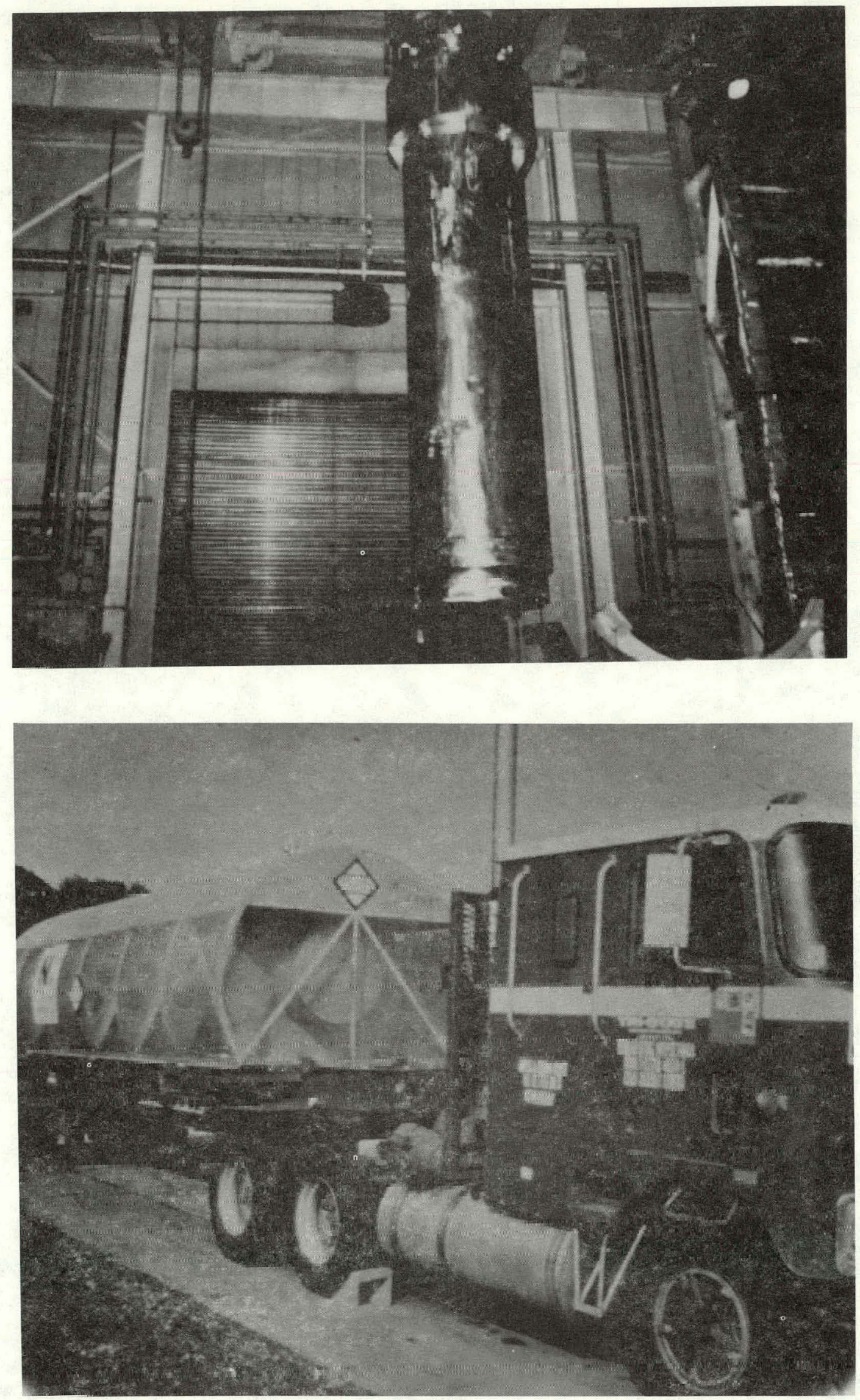

FIGURE 14

NLI Cask Being Lifted and Ready for Transport 

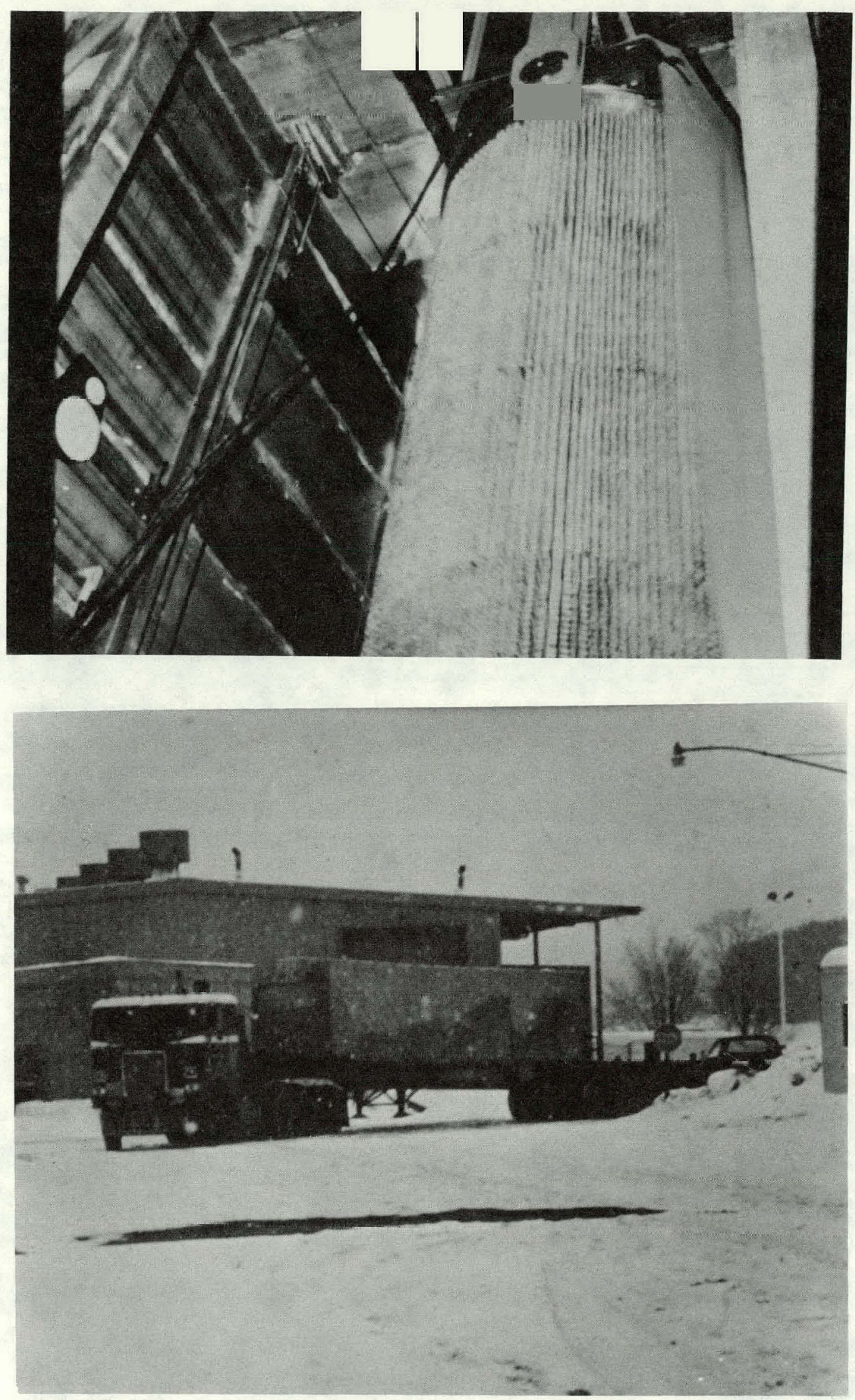

FIGURE 15

TN-9 Cask in the FRS Decon Stall and as Rigged for the Road

$$
\text { / - } 15
$$




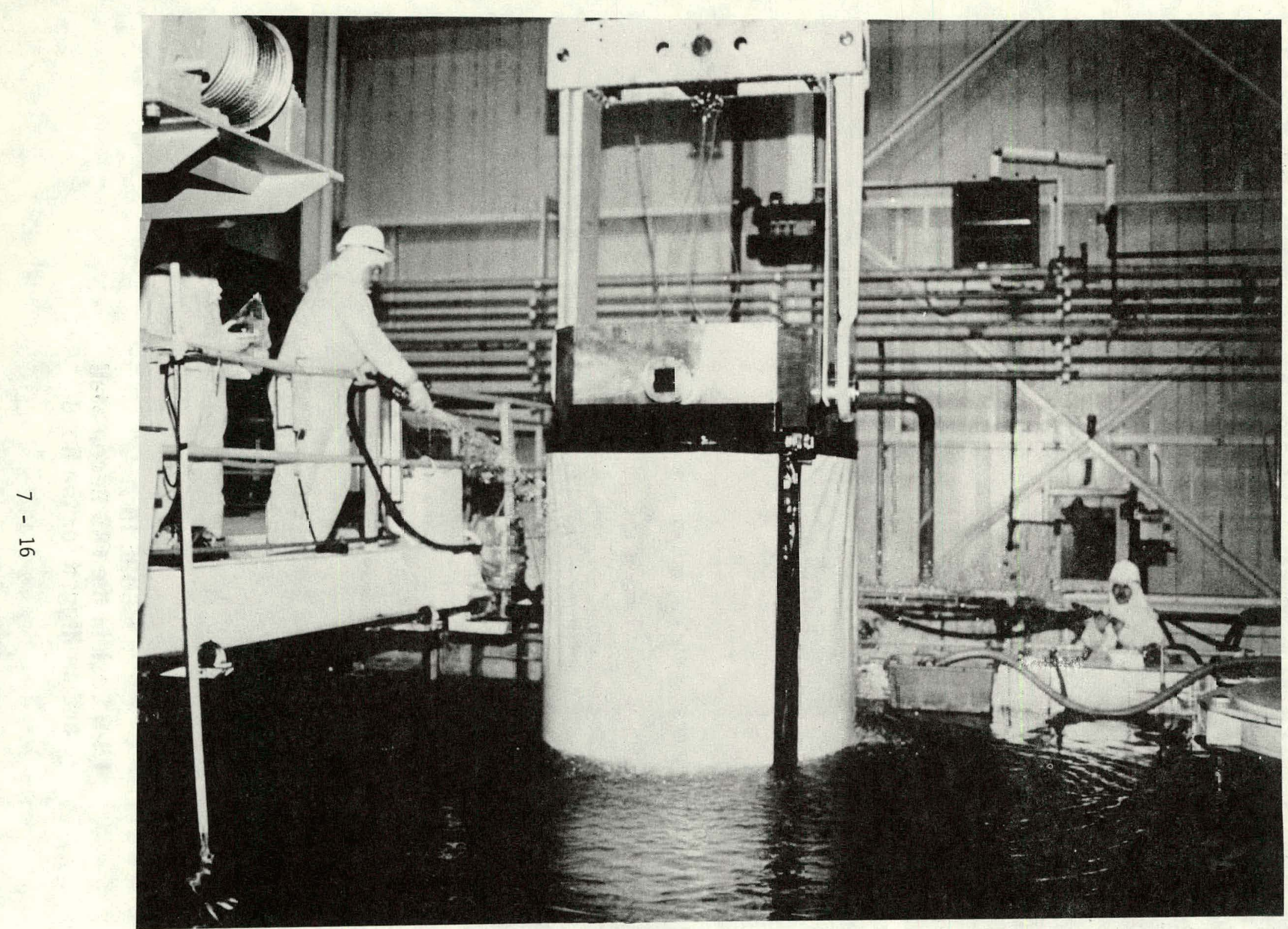

FIGURE 16

TN-9 Cask Being Withdrawn Fram the Pool 


\subsection{PUBLIC ISSUES AND RESPONSES}

The SNF removal program at WVDP had to be conducted, to some extent against a background of initially misinformed public, opposition group actions, public officials, and considerable media interest. Reference 3 reports on this phase of the program in more detail.

To inform the public and achieve a successful shipping program, emphasis was placed upon communicating with local groups and the media. These communications worked to facilitate the shipments and to generate acceptance of nuclear fuel transportation. Information programs were established which increased preparedness. for nuclear shipments by emergency response teams. The media was informed with. interviews and on-site press conferences.

\subsection{General Public}

The major issue concerning the general public is safety of the shipments. The most widely held misconception is that nuclear fuel is a liquid capable of leaking from its container.

The Speakers Bureau at the WVDP was utilized to meet these concerns of the general public. Speaking engagements to civic groups addressed nuclear fuel transport in detail.

In order to increase public education on nuclear fuel shipping, the spent fuel storage pool was included on virtually every tour of the project. Guests viewed the actual SNF assemblies, the shipping casks, and the workers who handled the SNF assemblies. 


\subsection{Environmental Groups}

The issues generated by concerned groups such as the Sierra Club, the Audubon Society, and the Environmental Policy Institute center on three areas: 1) terrorist access to a nuclear fuel shipment, 2) lack of crash testing on casks currently in use, 3) emergency preparedness teams cannot handle a nuclear fuel accident.

These issues were addressed in press conferences and in speaking engagements with.public officials, civic groups, and emergency preparedness teams. The terrorist question was discussed by emphasizing the preplanned routing, escort vehicles, safety checks, confidentiality of shipping times, and the ultimate durability of the casks. On the issue of cask testing, the Sandia cask crash tests were shown stressing the similarity between those casks and the ones used today. Computer as well as prototypical testing was also accented.

\subsection{Public Officials}

Most important to public officials and law enforcement personnel were the issues of routing, escort vehicles, and notification of shipments.

Site conferences held by project managers for local of ficials served to answer these questions. The shipment routing was detailed, use of escort vehicles was addressed and confidentiality of shipping times was explained. Officials were given a tour of the fuel. storage area where they saw the casks and transport trucks and met the managers who directed the transfer program.

WVDP and utility company speakers have also given presentations to community of icials upon request. This has afforded many opportunities to answer questions and clarify transport plans and procedures. 


\subsection{Media}

The West Valley Nuclear Euel Transfer Program has been covered widely in the media for a number of reasons. The transfer is the result of a court order stemming from litigation between utilities holding title to the fuel and New York State, the owner of the storage facility. Media interest is heightened because the shipments consist of highly radioactive spent nuclear fuel. Furthermore, these shipments travel on major highways and the transport times are confidential.

West Valley officials reasoned that their open communications approach established at the project would serve to generate confidence in the fuel shipping program. A press conference was held prior to the start of each SNF transfer campaign with support from each utility. Fact sheets emphasizing emergency preparedness and the safety record of nuclear materials transport were given to reporters along with pictures of the cask, transport trucks, and the fuel storage pool. Media were taken to the fuel handling area to see first hand how the operation worked. Intervicwo with project managers were encouraged. Management was asked to emphasize safety, experience and technical expertise.

\subsection{Communications}

Communications wer'e strengthened signiflcantly by providing managers with media training. A key to the fuel transfers had been the coordination of information among West Valley officials, the cask owners, and the utility companies. This ensured consistent and correct information distribution. 
The West Valley Demonstration Project will coordinate with the Department of Energy (DOE) in 1987 to transport to INEL 125 SNF assemblies currently in FRS storage pool. This campaign will differ in several respects from earlier campaigns. First, the DOE has taken title to the SNF asBomblioo. Eccond, the fuel will liavel by rail in two new dry storage casks. Third, the transport route crosses more states than before. While the public communications program will gear itself to the particular needs of these rail transfers, the same general precept applies - accommodate the public with as much information as possible. Fulfilling the special needs of local officials and promoting operational safety to the general public and the media are important prerequisites to a.smooth spent fuel transportation program. 
9.0 SCHEDULE, COST, EXPOSURE AND WASTE DATA

It requires the effort of 18 to 20 people to transfer a PWR type SNF assembly from the FRS storage pool to the cask, onto the truck, and on the road to its destination. These people and their functions are listed in Table 8. Only six to eight of these people are WVDP personnel, and they are included in the schedule and cost data of Table 9 which also lists the personnel radiological exposures and the low level wastes gerierated.

\subsection{Planning and Preparation for Shipout Campaigns}

As shown on Table 9, planning for this SNF removal program started in calendar year (CY) 1982 and extended into the first half of CY83. Most of this work was engineering, procurement, and testing. The program costs for CY82 was $\$ 20 \mathrm{~K}$. The radiological exposure dose and waste generated was negligible. Preparation for the shipout campaigns began in early CY 83 and lasted throughout the year. This task included deconning and refurbishing the FRS. The program costs for CY83 was $\$ 210 \mathrm{~K}$.

\subsection{Shipping Operations}

Shipping operations for the four completed campaigns of the program 3tarted the last part of CY 83 and ended early CY 86 as shown on Table 9. These operations include all tasks and activities included in the four completed SNF shipout campaigns. The total program cost for CY84, 85, and 86 is $\$ 3911 \mathrm{~K}$. These costs include all program costs but as shown on Table 9, the shipout campaigns were the predominant tasks. 
The radiological exposure dose for the program so $f$ ar as shown on Table 9 is 46.1 Man Rem. The low level waste generated is 329.2 cubic meters (uncompacted).

\subsection{Fuel Rnd Consolidation}

The nuclear fuel rod consolidation program was a relatively minor study. As shown on Table 9, it lasted a little over a half year, and $i$ ts cost is included in the CY85 and CY86 costs. The radiological exposure was $2.5 \mathrm{Man}$ Rem, and only 6.4 cubic meters of low level wastes were generated.

9.4 FRS Pool Dismantlement

This task started in mid CY86 and will extend to mid CY87. The costs are included in the CY86. CY87 costs have not yet been established. As indicated in Table 9, the bulk of the LLW generated $\left(254.7 \mathrm{~m}^{3}\right)$ resulted from the canister dismantled work. 


\section{TABLE 7}

WEST VALLEY TO IDAHO NATIONAL ENGINEERING LABORATORY (INEL) SHIPP ING CAMPAIGN--SUPPLEMENTARY DETAIL

Owner/Shipper: Generating Reactor: Carrier: Cask Type:
Nuclear Fuel Services/US Department of Energy RG\&E's Ginna NGS and Consumer Power's Big Rock Pt. NGS Unknown - Transport Mode Projected to be Rail as of $3 / 86$ Two 100-ton dial purpose casks (transport and storage) designed for one-time usage. Designed by Transnuclear, Inc.

TN-REG*

- Capacity - 40 PWR assemblies TN-BRP*

- Capacity - 85 BWR assemblies

Total One-Way Trip Mileage: Actual rail mileage unknown at this time. (Highway mileage: 2,700)

Rail Transport Route: Unknown at this time

Total Number of Shipments: 1

*SAR's for TN-REG and TN-BRP currently are undergoing review by the NRC for cask certification. 
TABLE 8

MANPOWER INVOLVED IN SHIPPING ONE CASK

- $18-20$ people required to ship one cask

- 3 - 4 State Troopers Truck/Trailer Inspection/Escort

- 2 NYS DOT Inspectors Truck/Trailer Inspection

- 1 Truck Co-Ord Maintenance Coordination

- 2 Truck Drivers Drive Trucks

- 1 Diesel Mechanic WVNS Truck/Trailer Inspection

- 1 QA Inopector Verifies Jhipping Documents (BOL, RM3R, Pl vcedule)

- 1 Utility Representative Signs Shipping Documents

- 1 Shift Supervisor Facility Coordinator

- 3 - 4 Fuel Handlers Support/Road Crew

- 1 WVNS Technician Handles Shipping Paper

- 1 Security Inspector Security Inspection Tractor/Trailer 


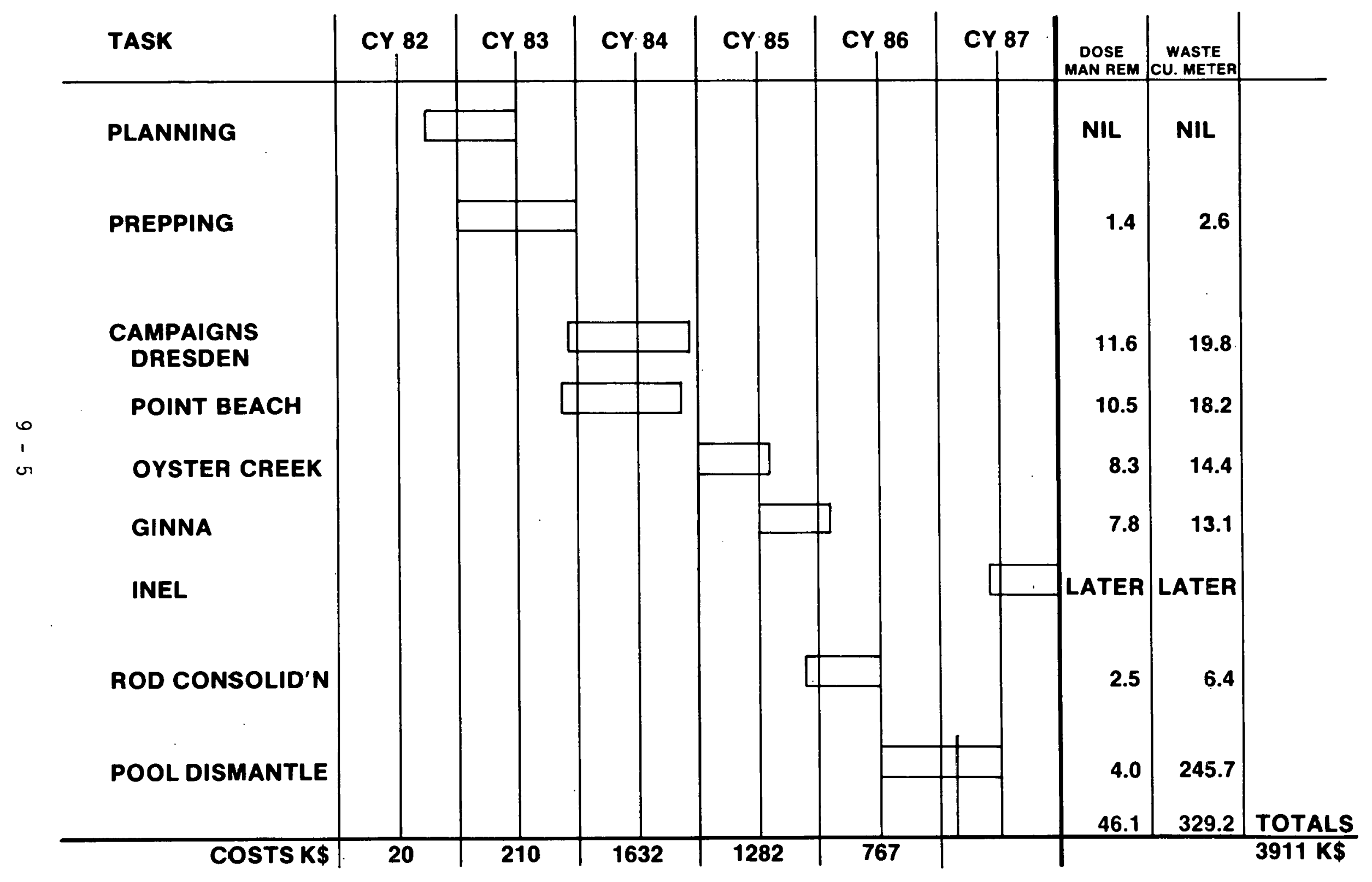

TABLE 9

SNF Removal Program Data Summary 


\subsection{LESSONS LEARNED}

As this SNF removal program progressed, there were some modifications to the original plans and procedures either to eliminate problems or to improve or simplify operations. In conclusion, the lessons learned are summarized in the following categories.

\subsection{FRS Operat1ons}

These operations and their procedures were well developed and shaken down during the FRS receiving campaigns during the 1973 to 1975 period. The significant lesson learned here was that these operations take more time than anticipated.

\subsection{Preparation for SNF Removal Campaigns}

The major lessons learned in these phases of the program are the time-consuming preparations and paper work involved in getting the transportation approved, and the time spent in public information. activities.

Communicating to the public and getting the media educated and involved are the keys to getting the SNF transportation on the road without hassles or interruptions. The time required for these activities should not be underestimated.

\subsection{Shipping Operations}

Almost. invariably there were truck or equipment problems which would require adjustment or fixing before the vehicle could pass the New York State DOT inspection. Scheduled time has to be allotted for truck and trailer maintenance on each shipment. 
WVDP contracted a local truck inspector to inspect the trucks and their equipment during FRS operations and before the New York State DOT inspection. In this way, any required repairs or maintenance was performed on the truck during FRS operations.

One shipper (trucking company) had a special on-site representative to arrange for any repair or maintenance work required on their trunks or equipment. This helped el iminatie last. minute delays due to equipment problems.

\subsection{Fuel Rod Consolidation}

The lesson from this developmental study is unexpected flexibility of fuel rods. It was expected that the rods would be severely embrittled during their burn-up in the reactor core neutron flux. As it was, their flexibility tended to hinder the compaction operations.

\subsection{FRS Pool Di smantlement}

As mentioned previously, the canister cutting rig was originally equipped with a high pressure water/abrasive jet for cutting the pool caniaters. Although this produced a flat, smooth, and accurate cut, the abrasive clouded the pool water reducing visibility for FRS operations and also clogging the pool filters. For this reason, the more labor intensive sawing operations were substituted for the high pressure water/abrasive jet. 
11.0 References

1. J. W. Halsey, Case Histories of West Valley Spent Fuel Shipments (Washington, D.C.: U.S. NRC, June 1986), Aerospace Report No. WPR-86 (6811)-1 (Draft)

2. W. J. Bailey, Rod Consolidation at the West Valley Demonstration Project (Richland, W.A., PN, October 1986), Pacific Northwest Laboratory Report No. PNL-5946 (UC-85)

3. W. Dean Hoffman, Spent Nuclear Fuel Transportation: Public Issues and Answers, Waste Management ' 86 
